\title{
7 Greek science and its language in Antiquity
}

Greek has been as hard to keep away from Latin as the sons of Israel from the daughters of Canaan.

Dirckx (1983: 106) ${ }^{1}$

\$1 Although this study is concerned with Latin, a brief chapter on its precursor language in Antiquity is indispensable due to the significant influence of the latter on the former. All through the history of Latin up to the fall of Constantinople (1453), Greek continually influences Latin developments, as the motto quotation points out. This chapter will be limited to considering early candidates for being called 'scientists' (§§2-3), Plato ( $\$ 4)$, Aristotle ( $\$ \S 5-6)$, and Hellenism and some glimpses of later developments $(\S 7) .^{2}$ Chapters 3-4 above have already traced the

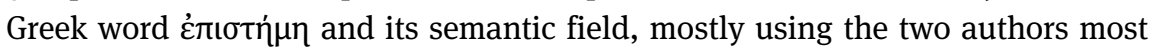
influential for epistemology and science in later times: Plato and Aristotle. We found that our modern categories of science, philosophy, religion, magic, technology, and the like (as used in chap. $4 \S 8$ above) did not yet exist separately in early Greek thought; rather, they can be said to be in statu nascendi from earlier 'lore'. ${ }^{3}$ This is the time and the environment in which the Greek scientific Denkstil is born; in Aristotle and Hellenistic scientists, it is already found in a very developed form. What many of the earlier authors quoted in the next few sections did and taught may at best belong more to one of our modern categories and less to others. So, while there are a number of important scientific insights and new methodologies in early Greek times, few of the men involved could be called 'scientists' first and foremost.

Concerning the relationship of language and science, the Greeks themselves in classical times do not show much interest in foreign languages (spoken by ßáp$\beta \alpha \rho o \mathrm{l})^{4}$ - consequently, they are hardly ever conscious of differences between the use of their own language and others. The importance of language in convincing

1 In a somewhat different context, speaking of Greek and Latin words and parts of words in English.

2 Lloyd $(1970,1973)$ provides general introductions to the study of Greek science before and after Aristotle respectively. Clagett (1955: 22) similarly proposes four periods for Greek science: 'pre-Socratic', Plato/Aristotle, Hellenistic, Roman. Remarkably, his book treats Greek science in Roman times down to $\mathrm{AD} 600$ in detail too.

3 Cf. the title of Burkert (1972).

4 See Momigliano (1975). Aristotle, De philosophia, frag. 35 Rose (from Diogenes Laertius, De vita

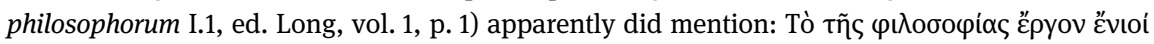

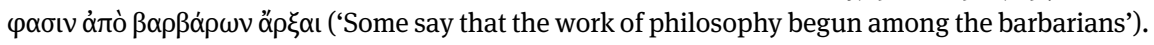
But language is not mentioned in the surviving fragment. 
people of one’s own point of view is one of the main points of the sophists (§3), but inherent limitations of natural language are a rare topic among Greek scientists; indeed, the Greek language seems singularly apt to being easily extended for scientific use (see chap. 22). Such limitations are more often discussed by later mystics, who stress the ineffability of their experiences. Examples are Plotinus or, more importantly for the Latin development in the Middle Ages, Dionysius Areopagita, who among other things states about the transcendent God (Mystica theologia 5, ed. Heil \& Ritter, p. 150):

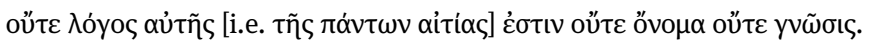
'there is no reasoning about it [the first cause, i.e. God], not word, nor knowledge.'

Church Fathers such as Augustine also often stress the ineffability of the divine. ${ }^{5}$ From this ineffability, Eriugena will conclude that God 'is' not, but 'is' superessentially (Periphyseon III.5, PL 634B-C = ed. Sheldon-Williams, vol. 3, p. 60):

Si igitur propter ineffabilem excellentiam et incomprehensibilem infinitatem diuina natura dicitur non esse, nunquid sequitur omnino nihil esse dum non aliam ob causam praedicetur non esse superessentialis nisi quod in numero eorum quae sunt numerari eam uera non sinit ratio dum super omnia quae sunt et quae non sunt esse intelligatur?

'Therefore, if it is on account of its ineffable excellence and incomprehensible infinity that the divine nature is said not to be, does it follow that it is nothing at all, when not-being is predicated of the superessential for no other reason than that true reason does not allow it to be numbered among the things that are because it is understood to be beyond all things that are and that are not?' (Trans. Sheldon-Williams, p. 61)

An introduction to the field of the language of the via negativa can be found in Westerkamp (2006). In contrast, the Greeks hardly spoke about the advantages or disadvantages of their language for science or philosophy.

\section{'Pre-Socratic' 'science'6}

In coming to understand and explain, they rarely used careful observational data, or experiments, in support of their claims. Nevertheless, the problems that the Pre-Socratic philosophers identified, and with which they grappled, largely by abstract, rational arguments,

5 e.g. De doctrina christiana I.6(6), ed. Green, p. 11.

6 The new edition of all relevant texts by Laks \& Most rightly avoids the traditional term 'pre-Socratic'; the general picture is heavily distorted by claiming that Socrates changed philosophy radically and single-handedly. 
formed the basis of natural philosophy as it would be shaped in the fourth century BC by Aristotle.

Grant (2007: 18)

\$2 Exploring the first scientific achievements sensu stricto is made difficult by the fact that very few primary sources of the authors in question survive in full; for those in the sixth century BC, no complete text at all has come down to us. As a consequence, there is little concord on these authors' scientific approach (or lack thereof), which also depends to a large degree on one's definition of 'science', as pointed out above (chap. 4). A comparison with extant Middle Eastern and Egyptian texts from the second and early first millennium BC show clearly that in Greece around the sixth century a new inquisitive, 'scientific' Denkstil emerges. The extent to which it makes sense to see science as the further development of this Greek Denkstil is discussed at the end of this book (chap. 24).

The earliest philosophers often credited with the invention of 'science' and philosophy lived and taught at their own private schools in the Ionian city-states of the sixth century, ${ }^{7}$ beginning with the Milesians Thales (ca. 624-ca. 546), Anaximander (ca. 610-ca. 545), and Anaximenes (ca. 585-ca. 528) and continuing elsewhere in this melting pot of Greek and 'oriental' cultures (especially Babylonian, Assyrian, Lydian, then Persian), such as Samos (Pythagoras, ca. 570-ca. 510) or Ephesus (Heraclitus, ca. 520-ca. 460). Upon the Persian conquest, some of these men emigrated to southern Italy, where they continued to flourish in various schools (especially Pythagoras, Xenophanes) and produced new approaches (e.g. Empedocles, Parmenides).

There are two points of uncertainty: first, how much of the early Greek (e.g. Milesian) 'science' stemmed from oriental sources mostly inaccessible to us, ${ }^{8}$ and second, how much of it was actually 'science' and not just backward projection by later doxographers. The early oriental cultures are known for their 'wisdom' literature, which is clearly not of a scientific character. ${ }^{9}$ A typical example of a scientific feat is the alleged prediction of a solar eclipse by Thales, who was in the

7 For a summary of the historical background of these cities at the crossroads of many cultures, see Marek (2010: esp. 177-183).

8 West and Burkert have changed our knowledge of these contacts decisively. See e.g. West $(1971,1997)$ and Burkert (1969a, 2008), where the regional political background, especially the Assyrian conquests and the large number of displaced people in these times, is emphasised as the background against which Greek thought first becomes palpable for us.

9 There is a brief introduction in Burkert (2008: chap. 5). 
past often hailed as the father of science precisely for this. ${ }^{10}$ It seems clear now that such a prediction would have been unthinkable even for the Babylonians, who were in possession of astronomical data spanning centuries, and much more so for a Milesian, who could hardly have had access to records of past eclipses necessary to predict future ones, ${ }^{11}$ at a time when the sphericity of the Earth was still unknown and thus also a fortiori the mechanism of eclipses. Indeed, it can be shown how already in Antiquity, this myth developed out of an untrustworthy statement by Herodotus. ${ }^{12}$ Pythagoras and the Pythagoreans are often credited with the invention of the sciences of mathematics and music theory, although hardly any of their achievements can be confidently dated back to their founder or his first pupils. ${ }^{13}$ Heraclitus might be taken to attest (although not to approve of)

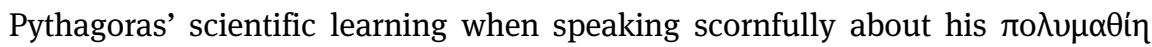
(D20 LM = 40 DK), but he mentions it together with Hesiod's 'learning' about the gods, which will not qualify as scientific in any way. In fragment D26 LM = 129 DK,

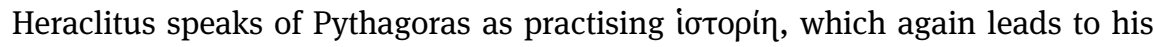

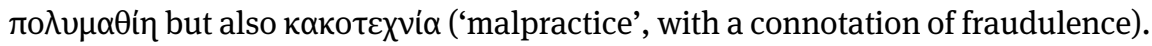
Pythagoras and his early followers can be contextualised well as a kind of shamanic miracle men, ${ }^{14}$ but that they engaged in activities that deserve the term 'scientific' must remain at best conjectural.

Nonetheless, many of those sages did set out to study $\varphi$ vioı and are accordingly called $\varphi v \sigma ı \lambda o ́ y o t . ~ A l t h o u g h$ this concept roughly corresponds to our 'nature' (which is studied by natural science), it has some slightly different connota-

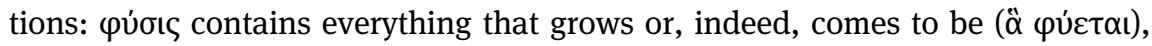
thus the entire phenomenal world. The mystical and religious character of this

10 The tradition of beginning philosophy and science with Thales and his pupils goes back to Diogenes Laertius (De vita philosophorum I.13, ed. Long, p. 5) and tends to be upheld by many modern writers, such as Lloyd (1970: 8).

11 Not to mention the necessary mathematical skills; see Neugebauer (1970).

12 As done in Mosshammer (1981). It is interesting to note that science has a tendency to produce hagiography and mythology for some of its 'heroes' (e.g. Galileo and the wrong idea that the Middle Ages thought the Earth was flat, respectively). Science should not be made a pseudo-religion, just as religion should not be pseudo-science.

13 The following largely follows Burkert (1972: 208-217, for mathematics: 401-420). See also von Fritz (1955).

14 Burkert (1962). The Greek term yónৎ comes close to our modern notion 'shaman' (which is abstracted from Siberian practices); the comparison goes back to Meuli (1935). Jan Bremmer voiced his disapproval, against which Burkert argues convincingly. Burkert also observes 'merkwürdig

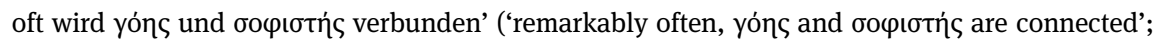
1962: 189). 
vast entity was rightly pointed out already by Cornford (1912). ${ }^{15}$ Thus, this 'all' is not far removed from what the neo-Platonists will call $\pi \lambda \eta \dot{\rho} \omega \mu \alpha$ : a divine, self-enfolding totality of being. This is what the $\varphi v \sigma ı \lambda$ óyo tried to understand, at first with approaches that can hardly qualify as scientific except, perhaps, insofar as there was a critical spirit and free debate among the sages. ${ }^{16}$ In fact, some of the most renowned sages of the sixth century were already combined into a group in Plato's time: the 'Seven Sages', whom Plato lists as Thales of Miletus, Pittacus of Mytilene, Bias of Priene, Solon of Athens, Cleobulus of Lindus, Myson of Chenae, and Chilon of Sparta (Protagoras 343a). They are by and large more statesmen or law-givers than philosophers or scientists, and provide another hint that Thales should rather be seen in that context too. Lloyd sees science's birth in the rejection of magic, a term he understands in a wide sense. He thus sees its novelty in the will to find necessary causes of phenomena. Some fragments from the Ionian philosophers indeed appear to indicate their preoccupation with principles and causes. About Anaximander we hear (P5 and D6 LM = A9 DK, known from Theophrastus):

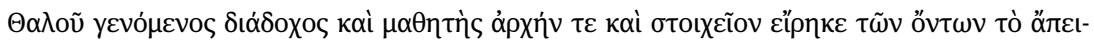

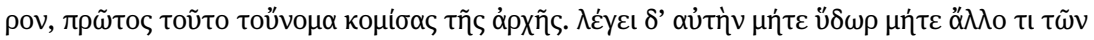

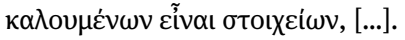

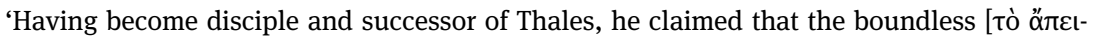
$\rho o v]$ was the beginning and fundamental principle of what is; he was the first to use the term "principle" [ópxท́]. He says that it was neither water nor any other of the so-called elements, [...].'

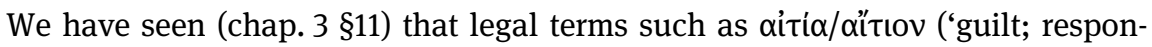
sibility; cause') acquired a philosophical and scientific meaning, shifting from being 'responsible, culpable' for something to 'causing' it. Herodotus uses these two words 91 times in his Histories: he was clearly looking for reasons behind historical facts. Hippocratic authors, such as that of De arte (late fifth century, ed. Jouanna et al.), are also looking for causes of diseases. ${ }^{17}$

Indeed, in the fifth century more convincing examples of scientific insights are found. Among the philosophers, traces of lasting scientific advances can be

15 But Cornford cannot be followed when he wants to trace those $\varphi v \sigma ı \lambda$ óyot as going back behind a postulated development of Olympic divinities, who hold sway over one province of being each, to a more 'primitive' and mystic-holistic point of view with a non-personal divinity, Фúбıc. 16 As Lloyd (1970: 15) points out. But the same is true for the Upanishadic sages, who would not qualify as 'scientists'.

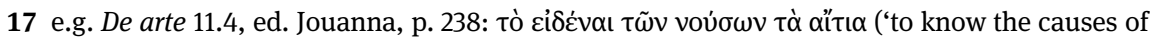
diseases'). 
found in Parmenides (ca. 540-ca. 480) and Anaxagoras (ca. 499-428). Aristotle seems to agree with our view when he makes natural philosophy begin with these two men. ${ }^{18}$ Parmenides had his own school at Velia (south of Naples); a bust of him from around $100 \mathrm{BC}$ was found there, hinting that his memory was still held high then, apparently as a kind of priestly physician (see fig. 8). ${ }^{19}$ He wrote a poem in hexameters treating the true nature of being in its first part, and the opinions of men in the second. Only fragments, mostly from the first part, survive. Parmenides is sometimes referred to as the father of logic, although this will also be a backprojection from later times, as his aims would seem to have been at least as much of a metaphysical or mystical kind than of a logical one - if he would have agreed at all to separate reality into such compartments. But it must not be forgotten that the second, apparently much longer, part of his poem dealt with the 'opinions of mortals, which cannot be truly trusted', ${ }^{20}$ which were apparently in their time an advanced scientifically based Weltanschauung that included novel discoveries, for instance in astronomy that 'the moon gets its light from the sun, the earth is spherical, and the morning star is identical to the evening star, ${ }^{21}$ Besides inductive science, deduction is also well developed in Parmenides, who offers the first attested case of a deductive chain leading from an axiomatic 'it is' to a number of

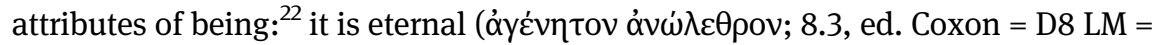

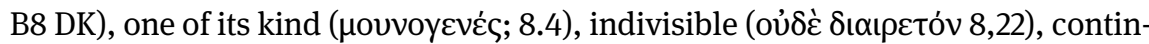

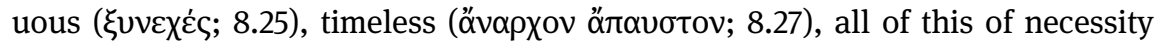

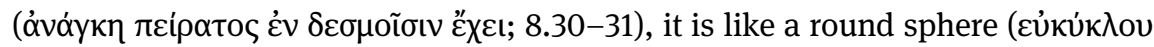

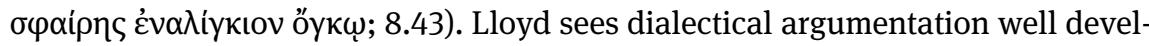
oped for the first time here. Indeed, in the 148 extant lines of Parmenides (frags 1-17) there are many logical particles - yó $\rho$ (31), غ̇лعí (9) - and 70 occurrences of the verb हivval. Parmenides writes in hexameters, thus in a language based on epic, Homeric poetry. ${ }^{23}$ In contrast, the first 148 lines of the Odyssey contain yó $\rho$ (6),

18 If we understand the hint in his lost Protrepticus (frag. 52 Rose = Iamblichus, De communi mathematica scientia, ed. Festa \& Klein, p. 79) correctly; see the edition by Hutchinson \& Johnson, p. 17.

19 See Burkert (1969b: 22) on Oủ入ı́ónc.

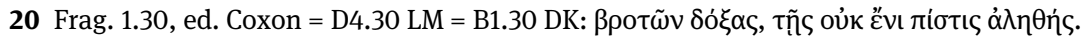

21 Graham (2013: 230). Cf. frag. 9 Coxon as a summary; frags 14-15 Coxon about the Moon's light; frag. 12 Coxon about five climate zones on a round Earth, explained more fully by Aetius (II.7) in test. 61 Coxon.

22 Similarly Lloyd (1979: 69-70). According to Lloyd (265), it is with Parmenides and Heraclitus that epistemological questions are first raised.

23 Its indebtedness to Homeric epic is clearly demonstrated in the introduction to Coxon's edition. 


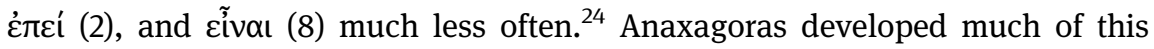
further, and among other things learned to understand the nature of solar and lunar eclipses, that is, that they are caused by the Sun's light being blocked (although he did not accept the Parmenidean round Earth). After him this view quickly became communis opinio. ${ }^{25}$ Anaxagoras changed the written medium and wrote his book in prose, of which again only fragments remain. Besides astronomical questions, it treated much of the physical world, especially noteworthy phenomena (much like Seneca's Naturales quaestiones was to do; see chap. 8 §8).

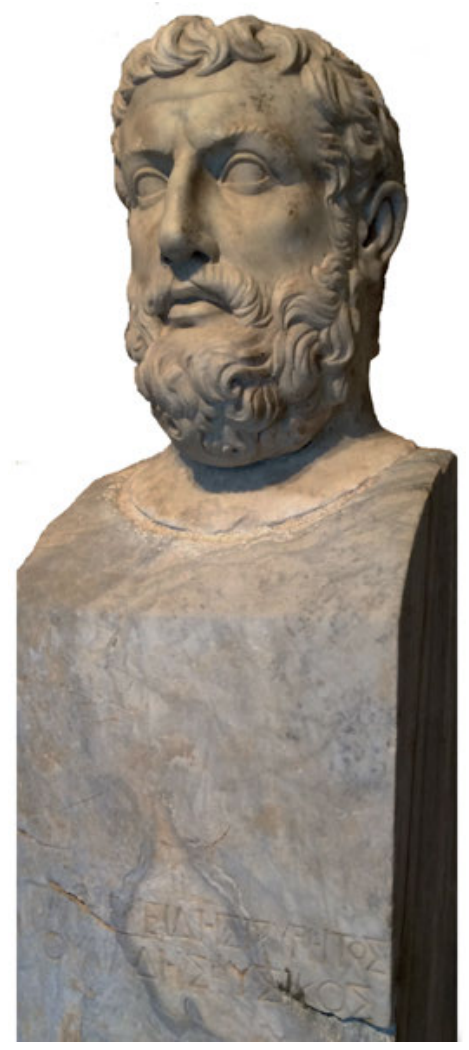

Fig. 8: Bust of Parmenides from his hometown of Velia, including the inscription П $\alpha \rho \mu v i \delta \eta\rceil$

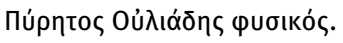

Source: https://commons.wikimedia.org/wiki/File:Busto_di_Parmenide.jpg (image by user Sergio Spolti, https://creativecommons.org/licenses/by-sa/4.0; modified).

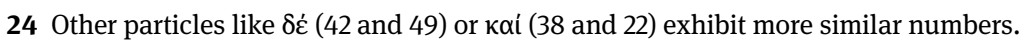

25 See Graham (2013: 216). 
Besides astronomy, geometry also seems to have developed into a scientific branch in the fifth century. Unfortunately, we are even less well informed about these beginnings. Geometry is in many respects an especially important science, as it was to become paradigmatic and its methods were copied within other sciences until at least early modern times (see §7). The important discoveries by Hippocrates of Chios (ca. 470-ca. 410), Theaetetus of Athens (ca. 417-368), and

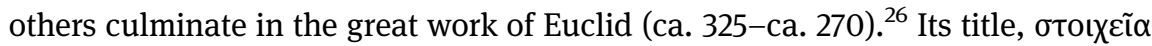
'arguments set in line,27 (see chap. 3 \$11 above), exemplifies its scientific nature; this work and its translations will be discussed in chapter 22.

Democritus of Abdera (ca. 460-ca. 370), who already belongs to the generation of Socrates, seems to be consciously engaged in shaping language to contain his thinking. Unfortunately, there are only some three hundred, mostly short fragments left of his numerous treatises. ${ }^{28}$ The LSJ dictionary lists 628 lemmata in which Democritus is mentioned, of which slightly more than one hundred are otherwise practically not or not at all used by any other Greek writer. A few examples follow. ${ }^{29} \delta \varepsilon \dot{~} v$ (as an opposite to $\mu \eta \delta \varepsilon$ ' 'nothing') denoted his atoms. This linguistically misconstructed word ( $\mu \eta \delta \varepsilon \dot{\varepsilon} v<\mu \delta^{\prime}$ ' $\varepsilon v$ ) was long thought to have been Democritus' invention, but now another instance of it has become known. ${ }^{30}$ The

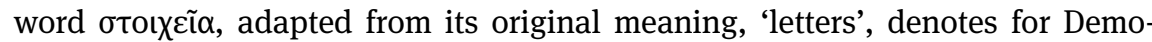
critus the atoms which make up things in a similar way to how letters make up words. Here are some words that are only known from him (translations from LSJ):

- $\quad \dot{\alpha} \theta \alpha \mu \beta i ́ n$ ('imperturbability’; D322 LM = B215 DK),

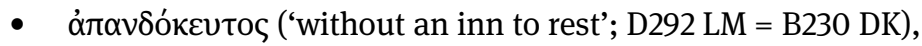

- $\delta ı$ เ

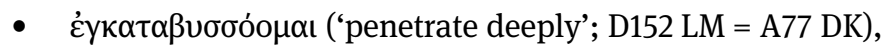

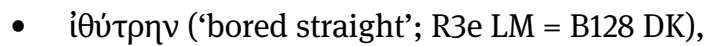

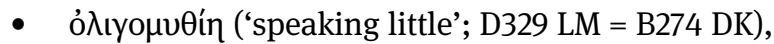

- $\pi v \kappa v \alpha ́ \alpha \mu \omega v$ ('close-fitted'; D117 LM = A93 DK),

26 The old mathematicians' works have nearly completely perished, as they were eclipsed by Euclid's Elementa. The above information stems from Proclus, In Euclidem 66-67, ed. Friedlein. It is discussed in Lloyd (1979: 108-115).

27 Burkert (1972: 402).

28 It is usually not possible to tell Democritus apart from his teacher Leucippus in the surviving fragments. 'Democritus' is therefore used to cover either of these two philosophers. DK has 298 fragments termed 'genuine'; as Laks \& Most do not differentiate fragments and testimonies, counting them is more difficult, but the number will not have increased greatly.

29 See von Fritz (1938).

30 See Burkert (1997: 32-33). 
- $\tau \varepsilon v \theta \rho \eta \nu i \tilde{\omega} \delta \varepsilon \varsigma$ ('honeycombed'; D192 LM = A155 DK),

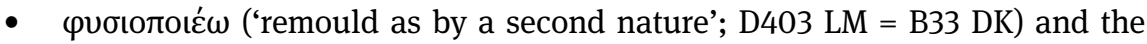
lists in R3 and R4 LM. ${ }^{31}$

Many of these words are compounds reminiscent of epic poetry. Against expectations, many of them are not nouns (although abstracta in -í $\alpha$ are also common); more frequently, they are adjectives (often in -ńs) or verbs (often in - $\varepsilon \omega$ or -ó $\omega$ ). Of course, Democritus also uses normal words technically, such as $\tau \rho \circ \pi$ ' ('position') or ṕvouós ('shape'). ${ }^{32}$ Such a linguistic approach, which easily coins new expressions for novel thought, stands in stark contrast to Plato (who did not coin any new words) and Aristotle (who did so, but rarely and quite differently). This approach to coining new terms is examined below (chap. 21).

In short, this evidence shows that while traces of scientific activities in the sixth century are meagre at best, things change significantly in the fifth. In addition to astronomy and demonstrative mathematics, this trend can be seen confirmed in Hippocratic medicine, apparently initiated by Hippocrates of Cos (fl. ca. 430). ${ }^{33}$ Among Hippocratic physicians, a new methodological approach can, for instance, be seen in the author of De morbo sacro (ed. Jouanna), who tries to find

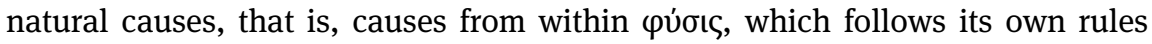
(no intervention by divinities), to explain epilepsy, a disease that was especially prone to be linked with the divine. Unfortunately his 'natural' explanations seem to us today just as fanciful as those given by his opponents, the temple healers: he believed that the veins carrying air and phlegm to the brain do not work properly. Although his reasoning does make use of causes, these are fanciful and untested claims and do not at all correspond to observable facts. Accordingly, his remedies against epilepsy (mostly dietetic) are likely to have had as much (or as little) effect as those of the temple healers. Nonetheless, his approach was more scientific, although for the layman the difference between the two ways of healing may not have been obvious. ${ }^{34}$ Some of these Hippocratic authors recorded not only their successes but also their failures in a scientific spirit, so that others could learn from them: ‘a quite unprecedented phenomenon' (Lloyd 1987: 124). It would cer-

31 Some of the words from LSJ are no longer found in the new edition by Laks \& Most, such as

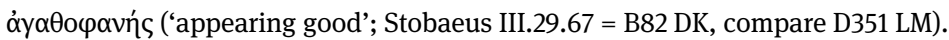

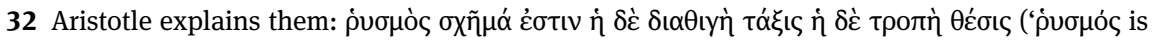

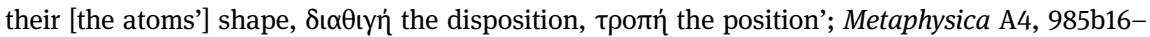
17).

33 Burkert (1972: 402), with references.

34 In fact, this difference between scientific medicine and other kinds of healing is often still unclear to the layman today. 
tainly be rewarding to study the Hippocratic authors' language further. The logical nexuses are strongly emphasised by some of them, for example by linking statements with yó . $^{35}$

Other scientific fields, such as historiography and geography, developed in a similar critical spirit during the fifth century. Hecataeus of Miletus (ca. 550-ca. 480) is said to have designed the first world map, and Herodotus of Halicarnassus (ca. 485-424) writes his Historiae in a spirit of trying to see events causally connected to one another. These later developments were already happening during the rise of sophistic rhetoric, pointing the way to Plato and his pupil Aristotle. The innovations in this period in natural philosophy, medicine, and history may well be addressed as a new Greek Denkstil; this Denkstil would entail a new, critical appraisal of the rôle of language. This became important among the sophists.

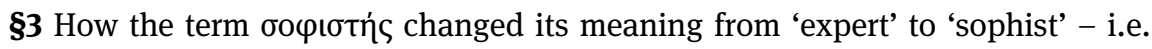
someone who takes money for teaching how to persuade people, regardless of the truth of the position - can be followed nicely in Laks \& Most (vol. 8, chap. 42). The sophists ${ }^{36}$ were certainly 'no self-contained group, let alone one that constituted itself self-consciously as a movement or school' (Lloyd 1987: 93). But this loose group of teachers can be said to be the inventors of higher education. ${ }^{37}$ What unites them is an interest in rhetoric and dialectic, a demand in Greek society for more than elementary education, the development of scientific subjects, a growing interest in political and moral questions. ${ }^{38}$ The realisation of the power and ambiguity of words was also very important in forming a consciousness of how convincing others - and at a later stage also oneself - can be achieved.

In historiography, sophist influence is patent in Thucydides (ca. 460-ca.

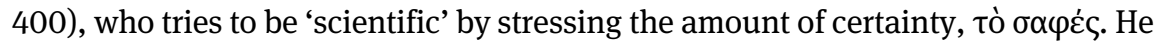

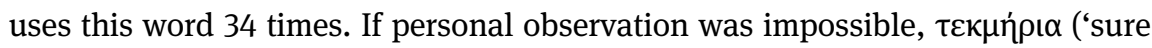
signs or tokens, proofs') were used; the same usage of these words occurs in some of the Hippocratic texts. ${ }^{39}$ When, especially for times long past, $\tau \varepsilon \kappa \mu$ ń $\alpha$ were

35 As observed by Lloyd (1987: 123) for De aeribus aquis locis.

36 Guthrie (1971: 204-219); von Fritz (1971: 223-227).

37 Burkert (2008: 58): 'it was the sophists who invented higher education as a new form of class distinction.'

38 See Lloyd (1987: 93).

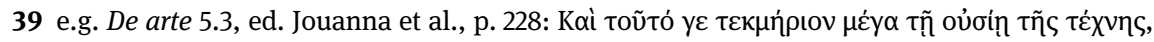

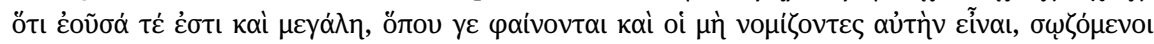

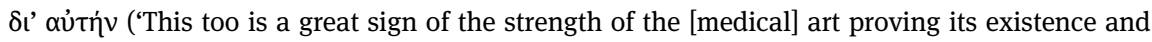
greatness, that also those who do not believe in its existence can be healed by it'). 
also unavailable, only tò cikós ('probability') remained (as later for Aristotle). ${ }^{40}$ In chapters 20-22, Thucydides speaks about the methods and goals of his history. An example (Historiae I.22.3-4, ed. Jones):

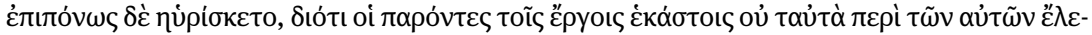

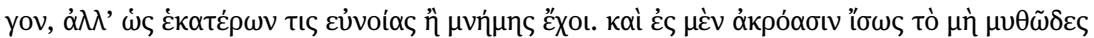

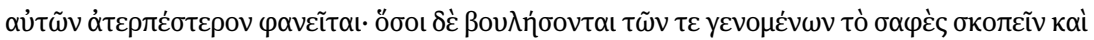

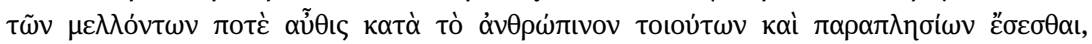

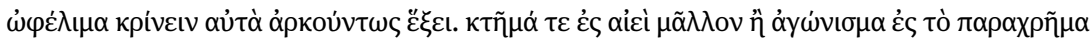

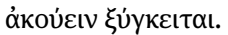

'[What happened] was discovered laboriously, for those present at the respective events did not report the same about the same things, but instead as goodwill and memory of each had it. The fact that the book lacks myth may render it less enjoyable for hearing, but to those who will wish to spot what is certain about past deeds, which according to human nature will be the same or similar again, it will be sufficiently useful. It is composed as a possession for all times rather than to hear applause in the present.'
\end{abstract}

Such a way of thinking is hardly imaginable without the sophist movement, but in contrast to it, Thucydides points out, he sets out to approach what actually happened as truthfully as possible, not to use the عikós merely in order to reach his own personal goals. As discussed above (chap. 3 §5), this may warrant speaking of scientific historiography. Laks \& Most offer good reasons (vol. 8, pp. 293-294) for including his contemporary Socrates (ca. 470-399) among the sophists. He did not commend his philosophy to writing, but his pupils Plato and (indirectly) Aristotle will be central for what follows. Both had their own private schools that continued to work long after their founders' death. ${ }^{41}$

\title{
Plato and his Academy
}

\$4 Judging from his extant works, Plato’s (mid 420s-348/347) interest in the natural sciences was rather limited. They do not figure in his utopian Republic, and indeed, only one of his many extant exoteric works, the Timaeus, is concerned with them. But to what extent scientific study was an integral part of his school, the Academy, and of his unwritten teaching is a much-debated question. ${ }^{42}$ Philosophy, rhetoric, and moral and political theory seem to have been central in the

40 See Lesky (1993: 517).

41 This may also have been the case with some of the 'pre-Socratics', especially Pythagoras and Parmenides, as well as Heraclitus through the Stoics - but it is less well documented and their influence was much less lasting.

42 For instance, Gaiser speaks of a 'Begründung der Wissenschaft in der platonischen Schule' ('foundation of science at Plato's school'; 1963: 14). 
Academy, but famous geometers such as Eudoxus of Cnidus also frequented it, and Plato's high esteem for mathematics becomes evident enough from the board at his school's entrance:

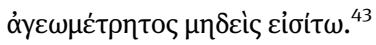

'No one who knows no geometry shall enter.'

First, some key passages in Plato's preserved, exoteric works are considered, and then a few words will be said about his handling of language. In the Timaeus, he

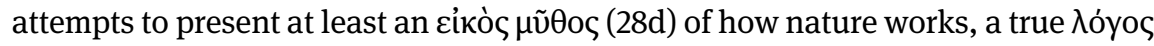
being impossible for non-necessary, non-ideal things (e.g. 27d, 29b). This unusual work will be the only one known directly in the Latin Middle Ages. In this dialogue, Plato uses mathematics (e.g. the five Platonic bodies) to explain the constituents of matter in a very speculative way; ${ }^{44}$ apparently, he reworks a lot of physical and biological theories from his predecessors. It is usually hardly possible to determine what is his own contribution and what comes from them, but Lloyd (1968: 88-89) argues that at least some of it is indeed his own. Lloyd is rather sceptical of the scientific character of the work and of Plato's approach in gener$\mathrm{al},{ }^{45}$ but concedes that the greatest legacy of Plato to natural science may have been his 'general belief in the mathematical structure of the universe and his ideal of the mathematical framework of scientific explanations' (91).

As discussed above (chap. 2 §2), Plato discusses in his Theaetetus what غ̇ंt$\sigma \tau \eta \dot{\mu \eta}$ is, here still taken sensu lato, as true 'knowledge' in general. The dialogue's results are mostly negative, but it does contain some key future terms. Plato shows that knowledge does not come from the senses and that there are difficulties in defining it as correct opinion ( $\dot{\alpha} \lambda \eta \theta \grave{\eta} \varsigma \delta$ ó $\xi \alpha, 187 \mathrm{~b})$, so this definition is improved by adding $\mu \varepsilon \tau \grave{\alpha} \lambda$ óyou (201c-d), concluding (202c2-3):

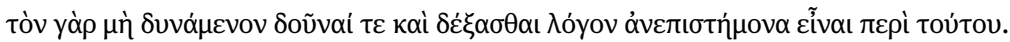
'for someone who cannot give or accept an account is without knowledge about it [the thing under discussion]. ${ }^{46}$

43 Preserved e.g. by Ps-Galen, De partibus philosophiae 2, ed. Kotre.

44 See Lloyd (1968: 90), who notes 'his general preference for abstract reasoning rather than observation'.

45 See Lloyd (1968: 92), writing that 'we should rather conclude that at no stage in Plato's life, either during or after the composition of his chief cosmological dialogue, did he consider that what we should call natural science is science in the fullest or highest sense of the term'.

46 The definition is taken up by Aristotle, Analytica posteriora II.19, 100b10; see Burnyeat (1981: 136). 
From 206c onward, the precise meaning of $\lambda$ óyos is sought, leading to the final attempt at a definition (208e):

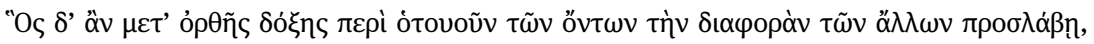

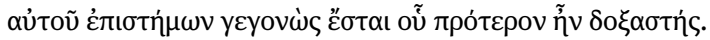

'Someone who adds the ability to distinguish from other things to a right opinion about anything: he will have become knowledgeable about what he previously only held as opinion.'

Knowledge able to distinguish the reason or definition ( $\lambda$ óyov [...] $\lambda$ ń something, truly understands it. In the Euthyphron (11a), 'definition' (in this case

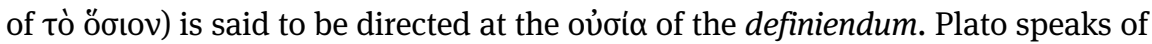

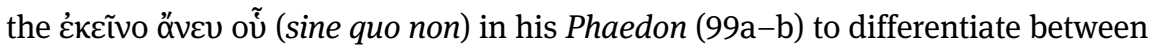
necessary causes and merely concomitant factors. This can be generalised: it is not only causes that reflect a scientific endeavour but also the desire in general to understand a phenomenon out of itself instead of just using it for some end or accepting opinions about it. Thus, mathematics can be said to arise when proofs are sought for claims, an approach that produced Euclid's Elementa. It is especially Plato who distinguishes strictly between the provably true and the merely probable, which latter must remain in the confines of mere $\delta$ ó $\xi \alpha$ and is thus - according to Plato - not susceptible to scientific study. Hence, his philosophy is hardly interested in 'physical' things treated by the natural sciences (excepting the Timaeus). In his Philebus, Plato marks clarity, exactness, and truth as the distinguishing characteristics of philosophical dialectics, in contrast to mere persuasion $(58 \mathrm{~b}-\mathrm{c})$ :

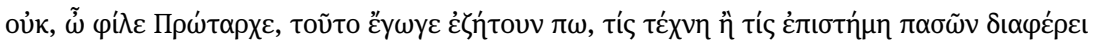

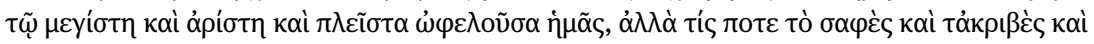

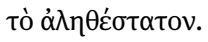

'I have not, friend Protarchus, just been seeking what kind of art or knowledge of all of them is distinguished as the greatest, best, and of most use to us, but what is the one that is most certain, exact and truthful.'

Besides these passages from his works for a broad public, one wonders what he stated in his esoteric works and possibly in his unwritten teachings. Already in Antiquity, there was a vivid discussion about the latter. The neo-Platonists with their hierarchical worldview, in which mathematics plays an important rôle alongside the Platonic ideas high up in the hierarchy, saw themselves as faithful pupils of Plato. Gaiser (1963: appendix) presents a collection of all the passages from Antiquity that mention Plato's unwritten teaching, and is able to deduce some basic characteristics from it. He sees the roots of science as we know it today more in Plato than in Aristotle. But this seems questionable: later chapters will make clear that these two approaches were both important for the development of 
science, but that Aristotle's more open and observational, less 'metaphysical' approach was of greater importance for acquiring new scientific understanding. Nonetheless, Gaiser is certainly right when he states: 'Platon hat, geschichtlich gesehen, zu der heute erreichten Mathematisierung der Natur den entscheidenden Anstoß gegeben' ('From a historical point of view, Plato gave the decisive impetus for the mathematisation of nature achieved today'; 1963: 38).

Besides his emphasis on the mathematical structure of reality, Plato's most important other contribution to the advancement of science will have to be seen in his strict and conscious employment of language, in which he was trained by the sophists' eristic use of it. Plato's view of the limits of language is expressed in the Cratylus. Socrates discusses with the Heraclitean Cratylus about whether (383a)

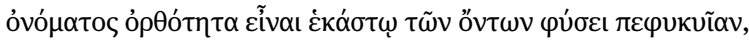
'the correctness of names is given by nature to each thing',

which Socrates attempts to refute. But the discussion remains on a terminological level; the wider question of the relation between statements and facts is - among the surviving texts - only really tackled by Aristotle's logic. Plato's practical approach to language can be studied better. He does not seem to coin any new words in his surviving texts at all; ${ }^{47}$ instead, he uses common words in specialised

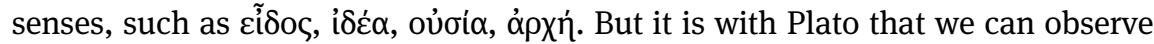
for the first time (in extant literature) philosophical concepts being formed into systems of terms that receive their precise meaning within the system. ${ }^{48}$ Examples collected by Eucken (1879) for such technical terminology contain many words of

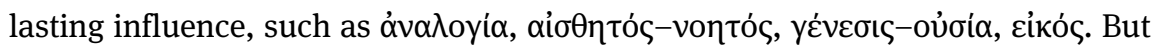
Plato tended to use several synonyms for some of his key concepts, as Diogenes Laertius (De vita philosophorum III.64, ed. Long, vol. 1, p. 147) already criticised:

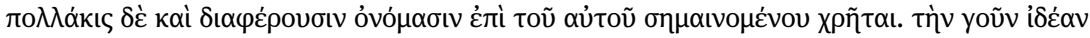

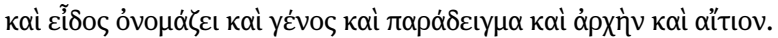

'Often he uses different words for the same concept. Indeed, he calls the "idea" also "form" and "genus" and "paradigm" and "principle" and "cause".'

There is a less obvious point in which Plato proved to be very important for the development of science: his "most trivial, "philosophical" view that spheres are "di-

47 Von Fritz (1938: 64; on the following words, see 52-61).

48 See Eucken, who speaks of 'das erste umfassende Begriffssystem [...]. Es bilden sich Gruppen und Reihen' ('the first comprehensive system of notions [...]. Groups and series are formed'; 1879: 17). 
vinely" or "transcendentally" beautiful' (Bochner 1969: 95). As von Fritz ${ }^{49}$ points out, this a priori aesthetic point of view was to stimulate the development of astronomy in a way that the more mechanistic but non-quantitative vortex theory of Democritus never could have. Plato's predilection for mathematics and for its beauty stimulated scientific research at his own school: Eudoxus of Cnidos developed the epicycle theory, probably on Plato's instigation (as von Fritz showed). His school, the Academy, was home to many important scientific advances; not least, it was the environment where Aristotle's mind was formed..$^{50}$ Among Plato's pupils, it was not only Aristotle who developed his approaches further: for instance, Speusippus seems to have studied the relationship between words and en-

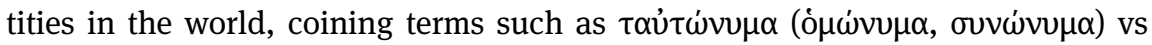

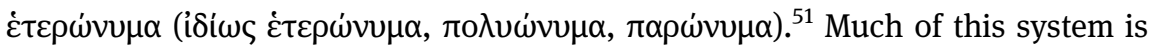
taken over by Aristotle. Plato's Academy continued to function as a philosophical and scientific school until Sulla destroyed it during the Romans' conquest of Athens (86 BC). In Christian times, a new Academy existed in Athens that claimed to have a continuous list of heads of school since Plato, but in the half-millennium in between, nothing is heard of it.

Vlastos (1975: 82-94) points out that Plato's ‘a priori' theories did take into account known 'hard facts' (e.g. by then, the sphericity of the Earth) if they were well established. Plato's 'naturalistic scenario' (97) leads to important theoretical advances. In the case of 'chemistry', however, his ingenious (although completely untestable) theory of matter being made up of triangles and squares does not have this effect - at least in Antiquity. ${ }^{52}$ It would seem that this is so because in chemistry the 'hard facts' were in his time basically everyday knowledge only. It may well be that Aristotle was aware of the lack of 'hard facts' in many fields and that this may have prompted him to start looking for and collecting new ones which could be used to build fanciful theories (something Aristotle enjoys hardly less than his teacher).

49 Von Fritz (1938: 180); this view is shared by Vlastos (1975: 63).

50 'Auch hat Plato die Einzelwissenschaften in der Akademie auf den verschiedensten Gebieten gefördert. Aber erst Aristoteles hat sie als Wissenschaften in systematischer Verankerung insgesamt etabliert' ('Plato also promoted the individual sciences at his Academy in a wide variety of fields. But it was Aristotle who first established them properly as sciences in a systematic embedding'; Flashar 2013: 368).

51 From frag. 32a Lang; see the study by Heitsch (1972).

52 Plato would certainly be delighted by modern organic chemistry, where geometric arrangements of atoms, such as the hexagon in benzene, are crucial. 


\section{Aristotle and the Peripatos}

In seiner Philosophie ist Aristoteles der zur höchsten Kunst des methodischen Denkens gesteigerte Ausdruck der weltanschaulichen Problematik seiner Zeit. In seiner einzelwissenschaftlichen Forscherarbeit dagegen ist er mehr, hier wächst er weit über seine Umwelt hinaus.

'In his philosophy, Aristotle represents the expression of the problems of the worldview of his time, elevated to the highest art of methodical thinking. In his individual scientific research work, however, he is more: here he grows far beyond his environment.'

Jaeger (1955: 428)

\$5 Aristotle, ${ }^{53}$ like Plato, published works and taught lectures both for a wider

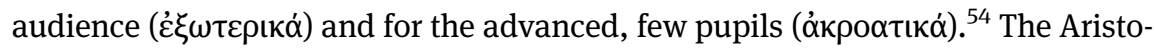
telian texts that survive today belong to the latter group; they can be seen as lecture notes in varying degrees of stylistic revision. In them, we see Aristotle trying to understand all the domains of the world around and within him with a scientific spirit aptly called by Wehrli 'umfassende Daseinserforschung' ('comprehensive exploration of existence'; 1944-1978: 10:100); the main concern of his approach to philosophy was clearly science - in contrast to Plato, for whom the ethical development of man seems to have been of greater importance. Due to Aristotle's lasting importance in scientific methodology, his use of language in science and his scientific approach are now considered in some more detail. ${ }^{55}$

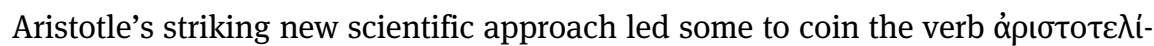
$\zeta \varepsilon{ }^{5}{ }^{56}$

Where Aristotle's scientific methodology is concerned, there is a significant difference between his theoretical writings about the scientific method and how he actually worked as a scientist, for instance in biology. ${ }^{57}$ The theoretical writings describe an apodictic, deductive character of science and strive for complete certainty, as detailed in the Organon and especially the Analytica posteriora. The aim of his work in practice can be described as 'scharfsinnige Strukturanalyse'

53 Still fundamental on Aristotle's oeuvre and methodology: Düring (1966). On his scientific method, see Kullmann $(1974,1998)$.

54 These terms are found in Aulus Gellius, Noctes Atticae XX.5.1, ed. Marache, vol. 1, p. 159: Alia

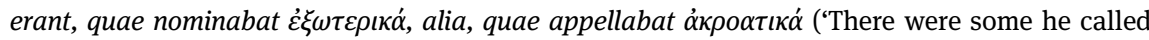
exoteric, some he called lecture notes').

55 For a condensed summary of the transmission of Aristotle's works in the Middle Ages, see Roelli (2020b).

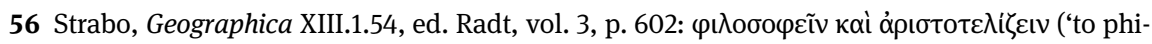
losophise and Aristotelianise').

57 This was pointed out by Düring (1966: 21-22). 
('astute structural analysis'; Düring 1966: 22) of a much more inductive character using methods that seem appropriate for the problem at hand. Lloyd wonders how Aristotle's important insight that scientific knowledge can hold good not only always, but also 'always or for the most part', can be squared with the formal, logical approach in the Analytica posteriora. ${ }^{58}$ The mathematical foundations for stochastics able to deal with such cases were, of course, not anywhere in sight. Lloyd (1987: 141-143) reaches the conclusion that Aristotle presents a pedagogic model of demonstration, a mere ideal, in the Analytica posteriora. ${ }^{59}$ Aristotle's actual practical approach is to begin with a collection of material (including earlier writers' opinions), then he tackles the question of why the material is the way it is, and then he tries to establish the characteristic structures in it synthetically (Düring 1966: 23). In this manner, he studied a wide range of phenomena scientifically, each with a methodology that seemed appropriate to it. Thus, Aristotle describes in the Organon one kind of science applicable to mathematics (and to some extent to what will be called the quadrivium), but employs a rather different one when the topic does not seem amenable to it, for instance in his zoology. Both these paths will find imitators over the centuries, and the discussion whether there can be 'real' science about uncertain, transient things - a central question in Plato's Academy - is kept alive. Deniers are, although under somewhat different circumstances and possibly more radically, still present today in the form of scholars such as Feyerabend (mentioned in chap. $4 \S 1$ above).

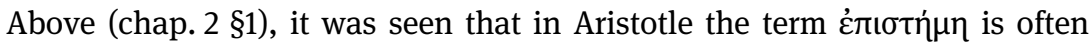
used to denote a special kind of 'knowledge', a 'scientific' one that can be divided into separate fields and that is based on structural understanding. ${ }^{60}$ In fact, the

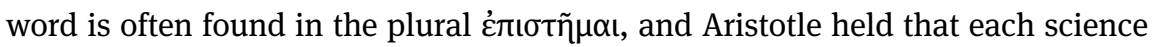
ought to be based on its own principles, thus establishing the concept of demarcated scientific disciplines. Although this step was very important for the development of the sciences, it also had questionable consequences, for instance when Aristotle refrained from using mathematics in the physical sciences. If it is accepted that the approach in the Analytica posteriora was, for Aristotle, not meant to be generally applicable to all sciences, we can look for descriptions of what $\varepsilon \dot{\pi} \iota \tau \dagger \dot{\mu} \eta$ is for him in his practical scientific works. He seems to be continually

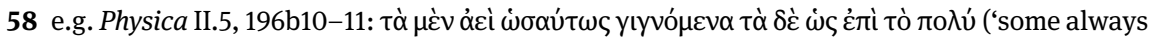

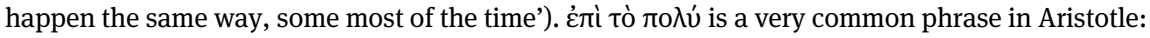
260 occurrences in Corpus Corporum. Mignucci (1981) studies some logical implications of using

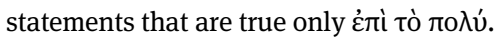

59 The problem is also discussed by Wieland (1970: 20), whose conclusion is that Aristotle lacked a comprehensive system.

60 Burnyeat (1981: 129) speaks of 'knowledge with full understanding'. 
looking for and remoulding its core meaning in these works. For Aristotle $\varepsilon \pi ı \tau \tilde{\eta}-$

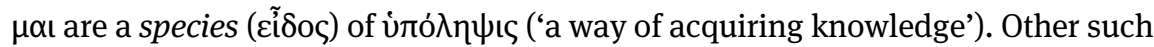

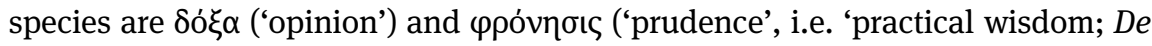

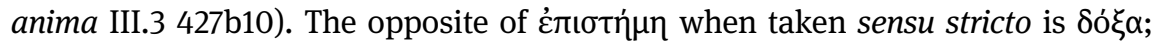
when meaning 'knowledge' in general, it is äyvoı ('ignorance, the lack of knowl-

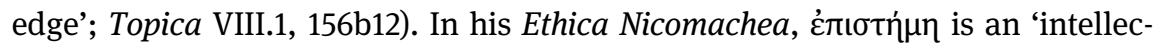

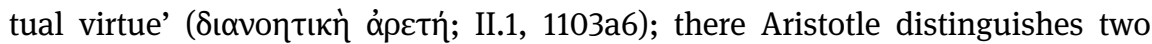
kinds of 'virtues': ${ }^{61}$ ethical ones and 'intellectual' ones - more precisely, those concerned with thinking or deliberating. Among these virtues, there are five species 'in which someone can be truthful by affirming or negating' (oíc $\alpha \lambda \eta \theta \varepsilon v ́ \varepsilon ı \dot{\eta}$

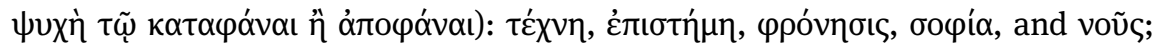
there are others that do not preclude being wrong, such as vंлó $\lambda \eta \psi \mathrm{s}$ in general and $\delta$ ó $\alpha$ (VI.3, 1139b15-17). These terms were studied above (chap. 3); they tend to be hard to translate into other languages and epochs. Only to some extent do they fit 'practically minded craft', 'scientific knowledge', 'practical wisdom', 'speculative wisdom', and 'intuitive grasping' respectively. ${ }^{62}$

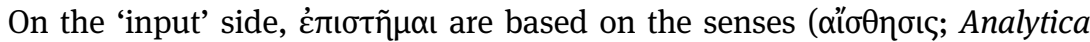

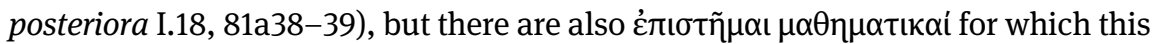
does not seem to hold (Metaphysica M4, 1078b7-17). They tend to be a generalised form of experience, but unlike it they are teachable:

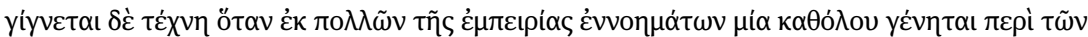

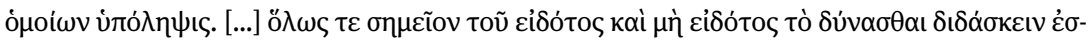

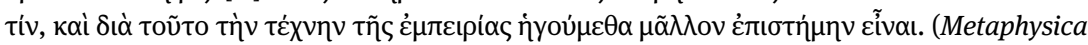
A1, 981a5-7, 981b7-9)

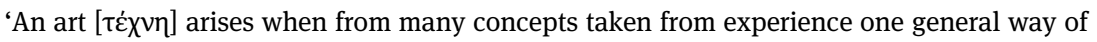
acquiring knowledge from similar cases arises. [...] The ability to teach something is clearly

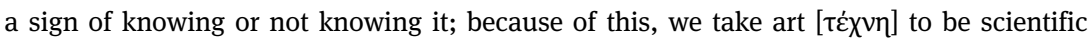
knowledge to a higher degree than mere experience.'

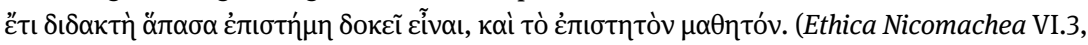
1139b)

'Further, all science seems to be teachable, and scientific knowledge learnable.'

It seems that for Aristotle there is a progression from mere experience to $\dot{\varepsilon} \pi \mathrm{l}$ $\sigma \tau \eta \dot{\mu}$, with $\tau \varepsilon \dot{\chi} \vee \eta$ wavering in between; apparently there are higher, more 'understanding' arts and lower, more merely practical ones. The former are described in Metaphysica A1, 981a28-30:

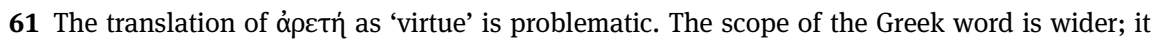
means quite generally the best possible state of something.

62 See further Flashar (2013: 88-91). 


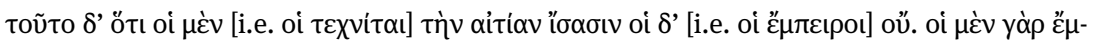

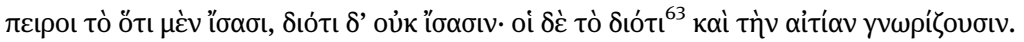

'This is so because the former [practical scientists] know the reasons, the latter [mere craftsmen] do not. For craftsmen know the "that" but do not know the "because"; the former also get to know the "because" and the reason.'

Such knowing the reasons or causes is typical of scientific understanding, as he points out a little later (Metaphysica A3, 983a24-26):

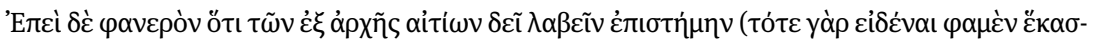

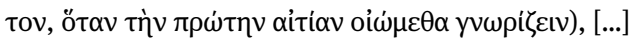

As it is obvious that one has to reach scientific knowledge from reasoned principles (for we claim to know something when we believe to have acquired knowledge of the first reason), [...] [Aristotle's famous four causes follow].'

The importance of causes has become a necessary part of science, at least until recently. ${ }^{64}$ It is still present in the proposed criteria for science, although in a somewhat more general way, in criterion II, which strives for step-by-step 'mechan-

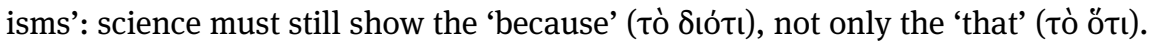

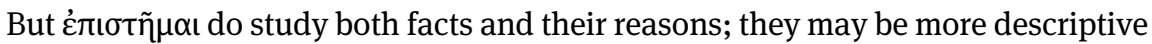
or explanatory. They are about general ${ }^{65}$ and measurable ${ }^{66}$ things. Seen from the other side - not that of their object but of the scientist - they are based on fitting definitions. ${ }^{67}$ From these arise $\lambda$ óyo ('conclusions') that find $\alpha \rho \chi \alpha i$ ('principles')

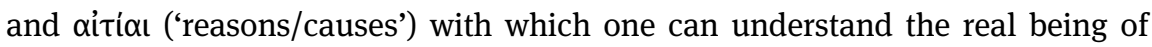
what is under consideration, 'that which it was' ( cess happens within voũ ('the intuitively grasping "intellect"'). ${ }^{68}$ Aristotle ety-

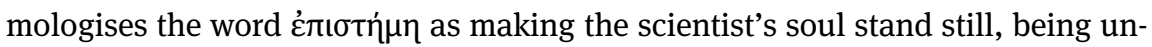
able to think or perceive well in chaos, ${ }^{69}$ so the word was felt to belong to the

63 Similarly in Analytica posteriora I.13, 78a22.

64 In the twentieth century, this concept becomes rather blurred by advances in mathematics and quantum physics, at least in some fields.

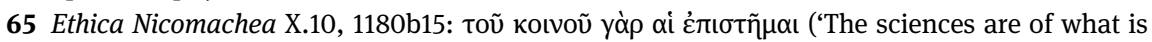
common').

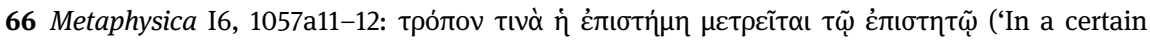
sense, science is measured by what is scientifically knowable').

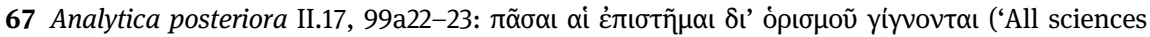
arise from defining').

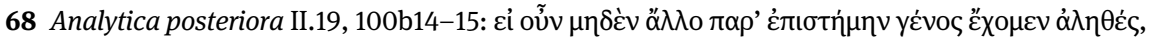

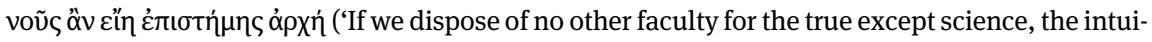
tive intellect [voũc] must be the source of science').

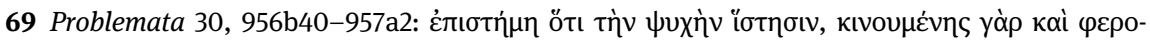

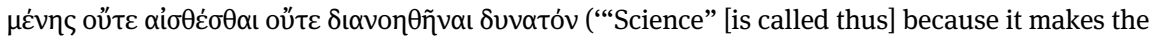




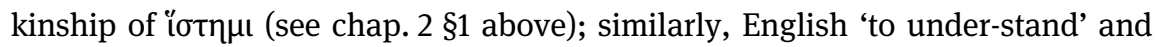
German ver-stehen. Something is understood when one has grasped its necessity, the fact that it cannot be different (Analytica posteriora I.2, 71b9-12):

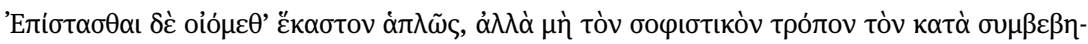

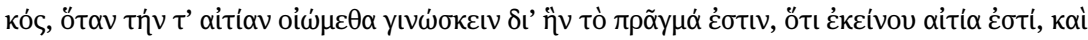

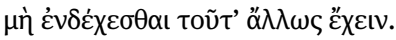

'We believe to have understood something simply (that is, not - as the sophists do - by means of accidentals) when we believe to have known the cause through which the thing is, that is, the cause of it, and that it cannot be different.'

Possibly even more important than Aristotle's emphasis on causation are logical rules that allow logically sound conclusions to be separated from ones that are merely able to persuade but lack logical rigour. The sophists' way of aiming purely at persuasion made Plato and his pupils aware of this problem. Aristotle formulated clear laws for what may be taken to be a logically sound conclusion from known facts and what may not. His basic writing on this subject, the Organon, will be of foremost importance in the re-emergence of his scientific spirit in the Latin Middle Ages. Aristotle himself seems aware that he had to start almost from scratch in developing logical foundations for science and philosophy (De sophisticis elenchis 33, 184a9-b8; the treatise's very end):

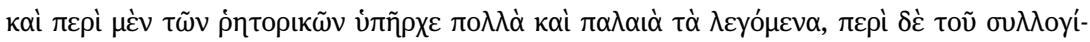

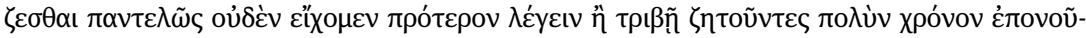

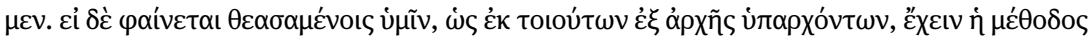

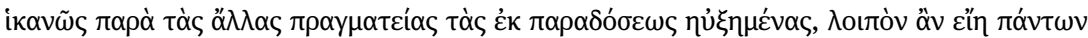

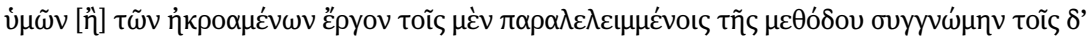

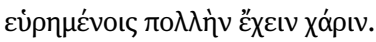

'And teachings about rhetoric have existed in great number and for a long time, but about the way of thinking [logic] we found absolutely nothing to quote, although endeavouring to seek arduously for a long time. But if it should seem to you beholders [of my logic], although beginning from scratch, that the systematic approach is appropriate in comparison with other disciplines which could be augmented from already existing stock, then it should be the duty of all of you listeners to show lenience toward the approach's shortcomings, but great gratitude toward what it has been able to establish.'

As often with Aristotle's statements about predecessors, this cannot be taken fully at face value: it should not be forgotten that questions of method and logic seem to have been discussed in Plato's Academy, as can be gleaned from the titles of

soul stand; the soul is not able to perceive or think when in movement and turmoil'). It is debated whether the Problemata are genuine, but at any rate they are a product of Aristotle's school. 


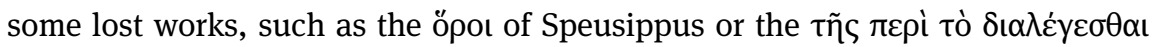

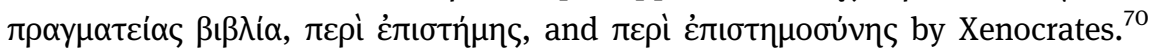
Aristotle's precise rôle can no longer be determined, as these works are completely lost.

Dialectics and rhetoric are for Aristotle faculties ( $\delta v v \alpha \dot{\mu \varepsilon} \iota \varsigma)$, thus prerequisites common to all sciences not themselves scientific disciplines. ${ }^{71}$ The list of logical fallacies in De sophisticis elenchis $(4,165 \mathrm{~b} 23-27)$ indicates what scientific language should avoid:

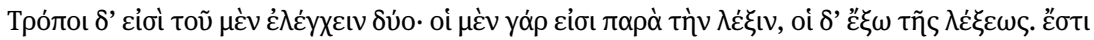

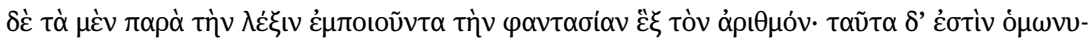

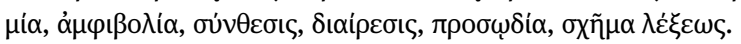

'There are two kinds of refutation: one is within language, the other outside of language. The ways of producing illusion within language number six: they are equivocation, ambiguity, combination, division, accent, and form of expression.'

Especially the first two show the importance of an unambiguous vocabulary. This leads us to consider Aristotle's approach to language. ${ }^{72}$ Aristotle uses words with

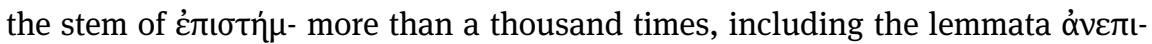

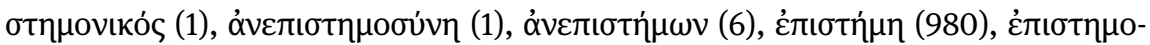

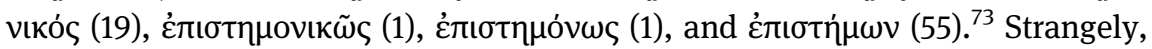
Aristotle does not seem to discuss in any of his many surviving texts how he sees his own highly sophisticated and - as far as we can see - rather idiosyncratic language. He does not address the relation of language and science in general, either. For Aristotle, language is a system of 'symbols' ('what happens to be thrown together with what is symbolised') based on states of the soul; these are the same for all peoples regardless of their language. Similarly, texts are 'symbols' of sounds. ${ }^{74}$ The problem of other languages and translatability only starts to be-

70 A list of their works can be found in Diogenes Laertius, De vita philosophorum IV.4-5, 11-14, ed. Long, pp. 165, 169-172.

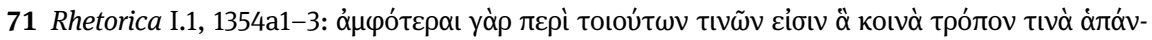

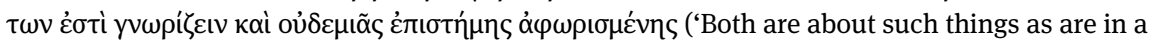
certain way common to the cognisance of all men; they are not confined to any [single] science'). See Lloyd (1979: 63).

72 In order to study Aristotle's use of words, the Index Aristotelicus by Bonitz is the fundamental tool; the Corpus Corporum and TLG search functions are also useful.

73 Data from $T L G$ (December 2017).

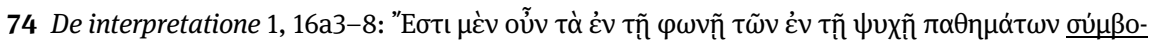

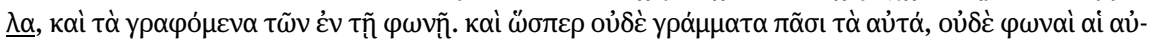

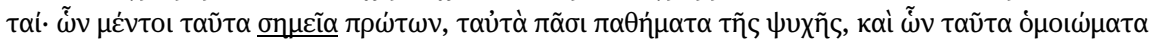

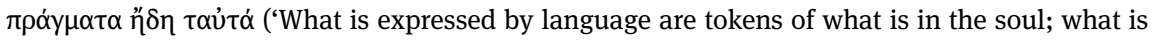


come acute when another language (such as Latin) takes over science from the Greeks and its exponents lose their proficiency in Greek, which happened some eight centuries after Aristotle.

The terms that, as far as we can tell, were first used by Aristotle are not very

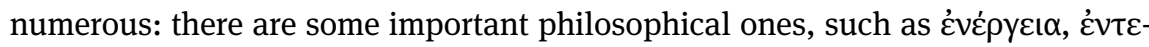

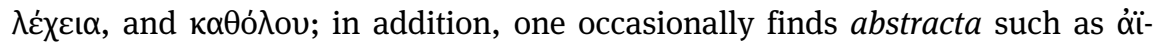

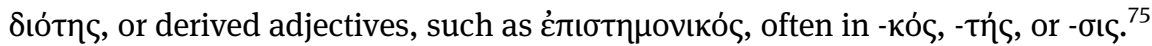
In his zoology, he occasionally needs names for groups of animals that do not

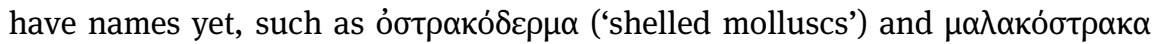
('crustaceans'); more rarely, there are similar cases in the physical sciences such as $\alpha$ ' $\tau \iota \pi \varepsilon \rho i ́ \sigma \tau \alpha \sigma ı \varsigma$ ('reciprocal replacement, interchange'). Many more words are given new shades of meaning or are used more precisely (von Fritz 1938 called

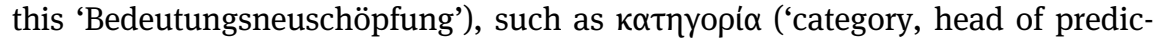

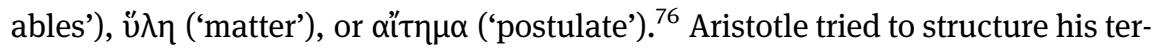
minology, often as pairs of corresponding terms, especially contraries. Eucken

written are tokens of what is expressed by language. And as writing is not the same for all peoples, so language is not either. But the affections of the soul of which these are tokens are the same for all men, and the things of which these are likenesses are also the same').

75 Eucken (1872: 25-26) collected a list of 'neue Ausdrücke' in philosophical terminology. Although in many cases it is not at all clear that Aristotle first used them, reproducing them here

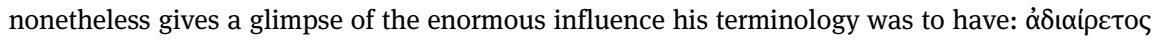

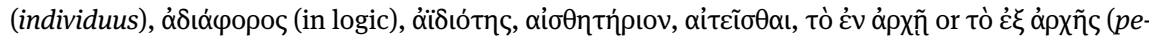

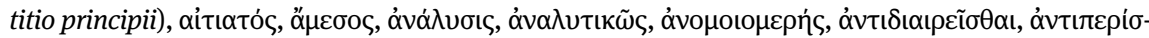

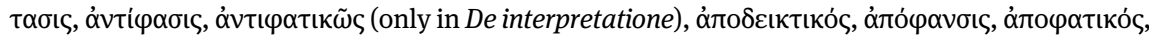

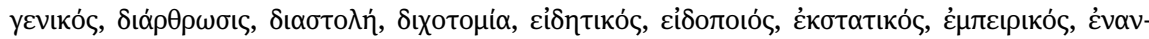

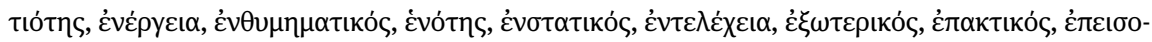

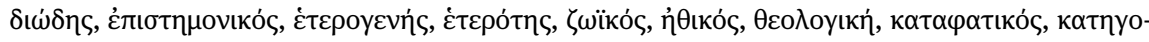

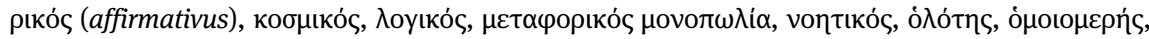

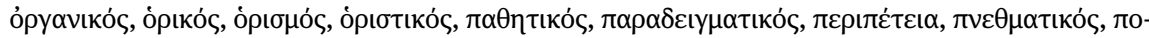

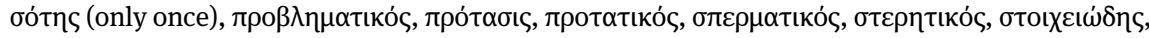

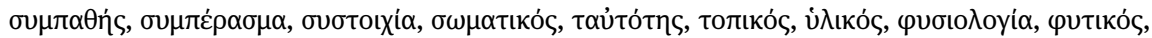
$\psi v \chi \iota$ เćs. Something similar to what we have just described for Aristotle's science can be observed here: today, we do not share the basic outlook (e.g. about the nature of Begriffe) of the great (mostly German) philologists of the nineteenth century any longer, but we still gladly make use of their abundant data.

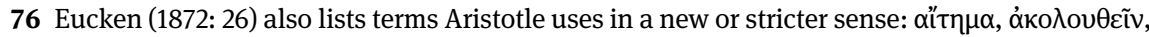

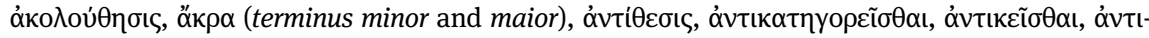

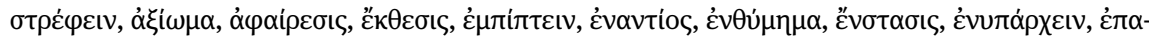

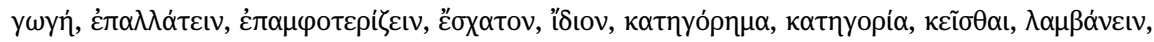

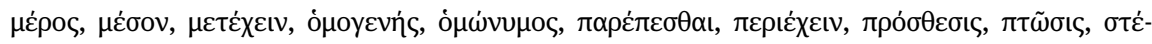

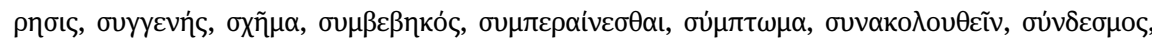

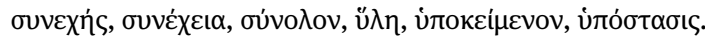




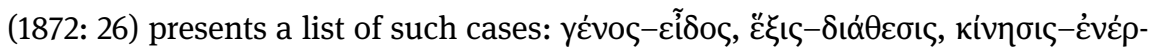

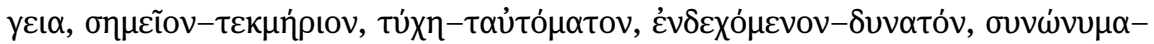

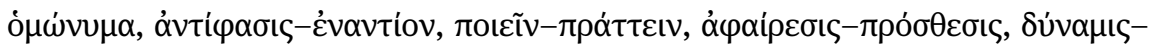

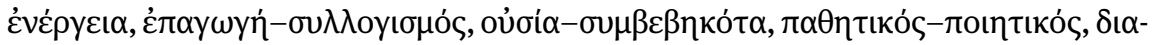

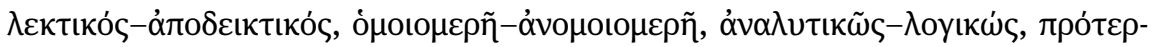

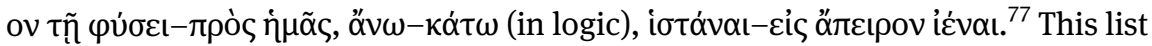
will not be discussed in detail; it is quoted here only to suggest to the reader the 'flavour' of Aristotelian terminology and to emphasise the importance of this kind of Fachsprache in the further history of philosophy and science. Aristotle not only laid the foundations of basic scientific and logical methodology for the times to follow; he also had a fine sense for the use of concepts, often deploring that his language did not have a word for a genus or a group of things that would logically require one. ${ }^{78}$ In general, Aristotle coins new terms when unavoidable, ${ }^{79}$ but more often he expresses novelty by means of words or syntagms from common language, defining them more precisely or using them somewhat differently, most fa-

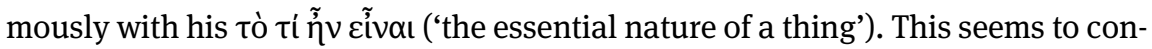
trast with Democritus, who makes extensive use of the Greek language's rich possibilities for compounding (examples in $\S 2$ above). The exceptions where Aristotle did coin new words involve words that look very different from Democritus' poetic-sounding ones.

For later translators of Aristotelian science and philosophy into languages that do not easily form new compounds (such as Arabic and Latin), Aristotle's language made life much easier than, for instance, Democritus' texts would have. ${ }^{80}$ As a brief digression, we can take a look at his two most famous coinings

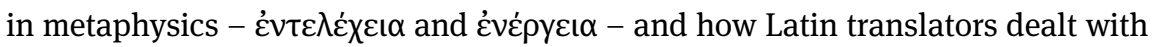
them: both words were notoriously untranslatable in the Latin Middle Ages. Much has been written about these two words; in both cases the formation does not seem to have been unambiguous even to native speakers of Classical Greek. Graham (1989) summarises the discussion about $\varepsilon^{\prime} \nu \tau \varepsilon \lambda \varepsilon_{\chi} \varepsilon\llcorner\alpha$ and points out that

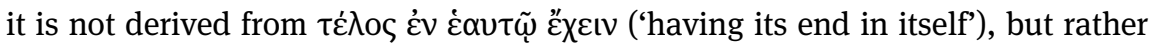

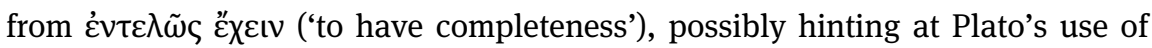

77 A shorter list which, however, discusses the individual items can be found in Kullmann (1998: 25-28).

78 He tends to call these instances óvúvvuos; for passages, cf. Bonitz (s.v.). Such cases are especially frequent in his works on ethics but occur also in those on the natural sciences.

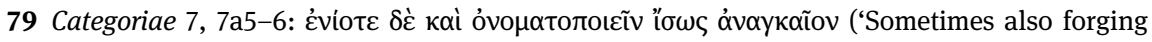
names may be necessary').

80 Democritus may have written as much, and on such varied topics, as Aristotle. But textual transmission in Antiquity has preserved the one and not the other. 


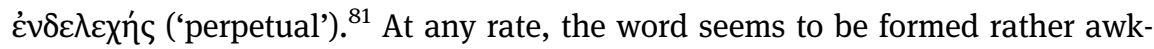
wardly, as new Greek compounds are usually clear enough to Greek-speakers. The oldest extant translations (by James of Venice and William of Moerbeke) of the Physica just write entelechia and may add id est actio. Later translators tended to simplify and just write actus, which, however, may also stand for several other

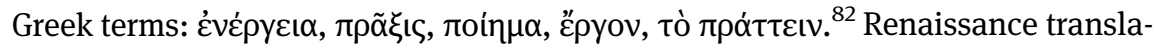
tors become more scrupulous about keeping Aristotelian concepts apart. Hermolaus Barbarus, apparently agreeing with the view championed by Graham, tries to translate it as perfectihabia.

Things are different for Aristotle's other new coining, that, although a near-

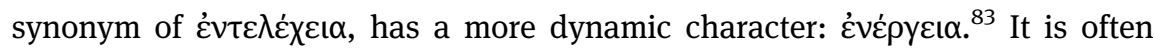

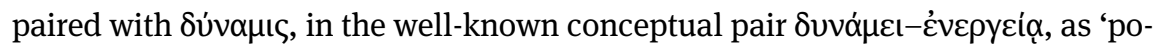
tentially' versus 'actually'. This distinction is an attempt to lessen Parmenides' paradox, in which things become being from not-being; instead, according to Aristotle, they come from potential being (Metaphysica $\Lambda 2,1069 \mathrm{~b} 15-20$ ):

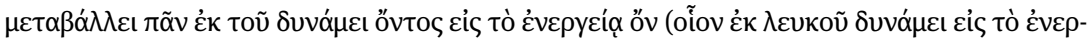

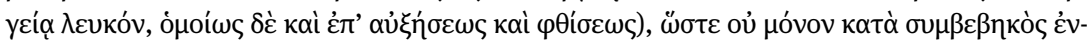

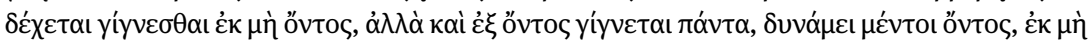

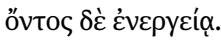

'Everything changes from potential being to actual being (like something that changes from potentially white to actually white, similarly with growth and decay), so that something can not only per accidens come into being from not-being, but everything can also come into being from being, though potential being, actual not-being.'

Both parts of this conceptual pair do not seem to have existed in Greek before

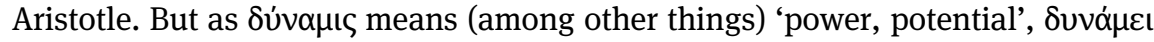
was easily understood as 'in power, potentially’. Menn (1994: 75) observes that

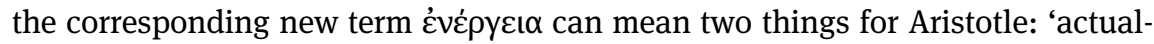
ity' and 'activity'; apparently, Aristotle first used the word to denote the latter meaning and progressively came closer to the former meaning. Aristotle also uses

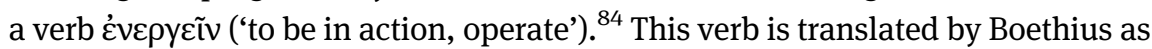
simple ago, by high mediaeval translators usually as operor. Renaissance translators often use actu sum, which fits better to actus in the established actu-potentia pair. The noun ćvépycı $\alpha$ is usually rendered as actus from the very beginning, but it will make history in modern physics in its Greek form as energia ('energy').

81 See the response in Blair (1993).

82 Data from the word indexes of the Physica and Metaphysica volumes of Aristoteles Latinus.

83 See Menn (1994).

84 Later also used for e.g. medical or sexual 'operations' (loci in LSJ, s.v.). 


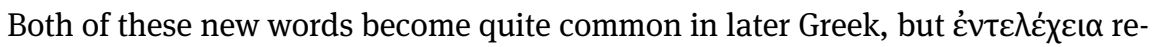
mained a typically Aristotelian term.

\$6 The contrast between scientific study before and after Aristotle - in Hellenistic times - is striking. ${ }^{85}$ Many sciences were first tackled in depth either by him or by students of his school, the Peripatos, ${ }^{86}$ which apparently for the first time provided an institution for organised scientific studies with its own library. ${ }^{87}$ It was only loosely organised into older teachers and younger pupils, and was in general open to the public (in contrast to Pythagorean circles). Düring points out that 'Aristotle created something quite new with his school. [...] finally, most important of all, the scientific outlook and the strictly scientific method' (quoted in Lynch 1972: 73-74). For Aristotle, غ̇лıтท́ nomena of all kinds using a variety of methods from mathematical and logical reasoning, observation (occasionally including simple experimentation), ${ }^{88}$ questioning people who observed a phenomenon, and an extensive use of written sources (in his large library) that had accumulated to a quite considerable amount in the two centuries before him. ${ }^{89}$ Aristotle himself added new data to the general 'stock', very clearly in his biological writings or his collection of constitutions of Greek city-states (see fig. 9). ${ }^{90}$ Although Aristotle’s own research has largely been revised in the subsequent millennia - he occasionally jumped from faulty observations to wide-ranging systems of thought built on sand - the main novelties in his own and his school's way of research lie in his detailed and organised programme for how to study things, including collaborators who took over some of the work and continued his school after his death, his self-conscious application of logic, and his thorough scrutiny of language, stressing the importance of precise definitions and differentiating between the different meanings of some words. Aristotle seems to have been the first person who thought methodically about the rôle of language in the expression of 'truth'; ${ }^{91}$ thus, according to the criterion of Léon Brillouin mentioned above (chap. 4 §6), Aristotle can be called the

85 See Lloyd (1979: 200). On the Lyceum, see Lynch (1972).

86 On which see Lynch (1972: 73-74).

87 On the Peripatetic school in Antiquity, see Moraux (1973-2001).

88 See Wöhrle (1986).

89 On Aristotle's way of working, see Flashar (2013: esp. 292). The sources are, unfortunately, largely lost to us today.

90 Collected by Aristotle and his collaborators; only the Athenian constitution has had the good fortune to be preserved on papyrus.

91 Plato's Cratylus may be seen as a predecessor. 
first scientist. We try to illustrate this with a few passages from Aristotle that display the features with which we tried to demarcate science above (chap. 4 §5).

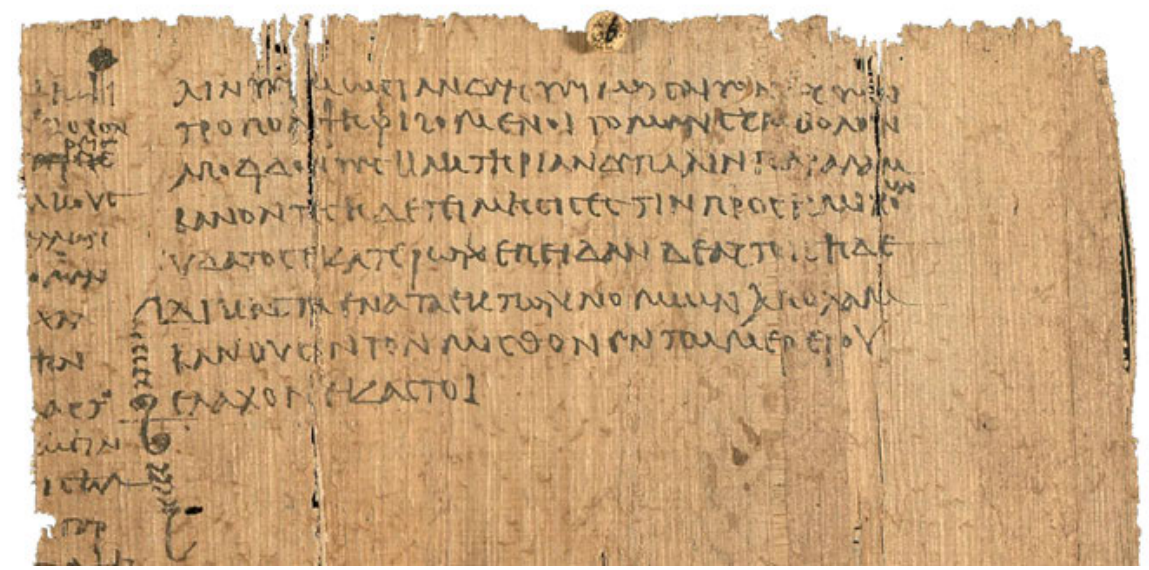

Fig. 9: The Athenian Constitution, the only surviving one of the city constitutions collected by Aristotle (British Library, Papyrus 131, part of 10v, the very end of the text, ca. AD 100). Source: https://commons.wikimedia.org/wiki/File:BL_Papyrus_131-10v_Constitution_of_ Athens.jpg (image by user Dbachmann, public domain, modified).

(I) Systematic method. Aristotle studies scientific method in detail in his $\mathrm{Or}$ ganon. This does not always square with his actual methodology, but the latter (e.g. in biology) is also systematic, just of a more inductive kind. Indeed, discussions of methodology are present in many of his other works. Kullmann (1998: chap. 2) deals with this topic in extenso.

(II) Mechanisms. Above, the importance of causation for Aristotelian science was stressed (Metaphysica A2, 983a), as well as the need to show the 'how' (tò

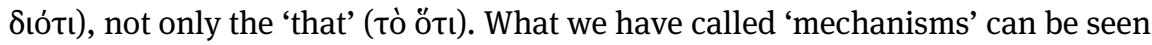
as a further development of this.

(III) Testability and impartiality. Examples of Aristotle's active gathering of data can be seen in many instances in his Historia animalium or in the collection of Greek city constitutions. In De generatione animalium, Aristotle points out that perception is to be trusted more than theory. ${ }^{92}$

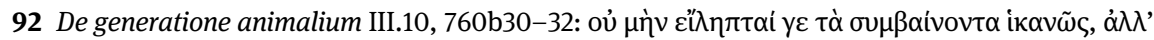

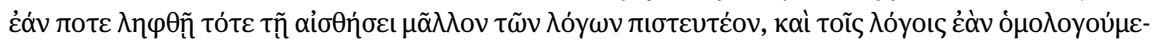

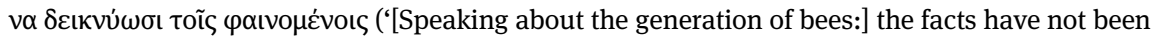
ascertained sufficiently, but once they will have been, then sense perception must be believed 
(IV) Non-sterility and coherence. Although we have seen that Aristotle stresses that every science needs its own principles, it is nonetheless clear that his sciences are interconnected. Much of the novel terminology, especially the pairs of contrasting terms, is used by Aristotle in many or all of them. The legacy of his research (or, in the above terminology, 'fruitfulness'), continued in the short run at his own school and in Alexandria, and in the long run in Arabic and Latin science, as will be shown below, is obvious.

(V) Community effort. The continued existence of Aristotle's school, where people did research and continued to teach for free and openly many generations after him, has already been mentioned. A good concrete example of community effort for Aristotle himself is, again, the collecting of Greek constitutions in order to study them, for which he collaborated with many people.

(VI) Formalisation. Aristotle formalised his language, as will have become clear above, especially in his novel pairs of contrasting terms. But he did not make much use of mathematical notation; in fact, no strictly mathematical works by him are known. ${ }^{93}$ In the Analytica priora, Aristotle uses letters to denote statements and lays the ground for formalised, syllogistic logic.

Of course, it may be somewhat circular to find the characteristics of (Aristotelian-based) science in Aristotle - 'Wenn jemand ein Ding hinter einem Busche versteckt' (Nietzsche). The point of doing this, however, is to show that similar criteria can hold good at least for Aristotelian and present-day science. The question of the extent to which science is linked to Aristotelianism and the Greeks in general is taken up at the end of this study (chap. 24). As for the language used: it has been pointed out that Aristotle did not reflect much about how language should be used in science, but we can still consider how he himself used Greek - we again test our criteria from above (chap. 4 §7).

(i) Well-defined terminology. Aristotle usually defines his key terms and takes care not to make definitions that are too distant from then current linguistic usage. For completely new concepts, he occasionally coins new terms (such as $\varepsilon v$ -

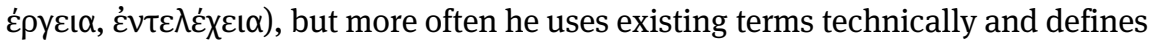
them precisely.

(ii) Unambiguity. The phrase $\pi о \lambda \lambda \alpha \chi \tilde{\omega} \varsigma \lambda \dot{\varepsilon} \gamma \varepsilon \tau \alpha$ เ occurs thirty-five times in Aristotle's works, ${ }^{94}$ which is proof enough of the stress laid by Aristotle on the fact

more than theory, theories [must be believed only] if they show agreement with what is observed').

93 His relationship to mathematics was studied by Heath (1949) and Cleary (1995).

94 According to a Corpus Corporum search covering both sequences: $\pi 0 \lambda \lambda \alpha \chi \tilde{\omega} \varsigma \lambda \varepsilon \dot{\varepsilon} \varepsilon \tau \alpha \mathrm{l}$ and $\lambda \dot{\varepsilon}$ -

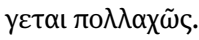


that language is often ambiguous and that the philosopher or scientist must therefore 'help' and improve natural language, making it a more precise tool.

(iii) Extendability. Some examples of newly coined words were listed above, but as Greek allows the nominalisation of phrases, this was often not even neces-

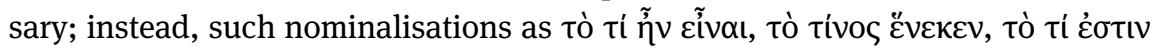
are frequently encountered. The Greek language makes meeting this criterion easy; it will be less so for Latin.

(iv) Perspicuity. The surviving Aristotelian works are in different states of redaction: some of them are very clear (e.g. most of the Organon and much of his biology); in others the reader can feel the author grappling with his topic (e.g. parts of the Physica and Metaphysica).

(v) Modality. The Greek language is quite rich in expressing nuances of certainty. It can use optatives, subjunctives, particles, and of course adverbs. Occurrence of some traits in Aristotle were counted and compared to average TLG Greek (January 2018). Many of them are indeed more common in Aristotle (lemmata):

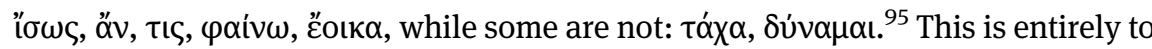
be expected, as such lemma frequencies depend a lot on personal style, but on the whole such words do seem to be more common than average in Aristotle. This aspect would need to be studied in greater depth.

The importance of Aristotle for the development of science in the long run will become obvious below: his works triggered Arabic scientific inquiry in the eighth century and the formation of Latin universities in the thirteenth. Well aware of this rôle, Dante calls him 'il maestro di color che sanno' ('the master of those who know'; Inferno IV.131, ed. Sanguineti, p. 25).

\section{Hellenistic science and beyond}

\$7 Aristotle's school, the Lyceum, later also known as the Peripatos, continued his approach for several generations; his successor as head of the school, Theophrastus (scholarch 322-288), was even more 'first and foremost a man of science. ${ }^{96}$ Unfortunately, there is very little left of later Peripatetic works except

95 Occurrences compared to the most common word (the article), × 1,000: ‘ $\sigma \omega \varsigma 1.4$ (TLG) vs 2.5

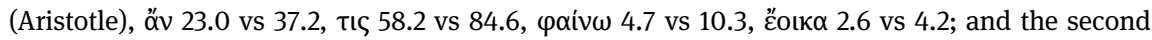

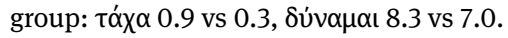

96 'Plato is a philosopher pure and simple; Aristotle is a man whose interest gradually turns from philosophical speculation to the study of detailed problems of natural science and history; Theophrastus is first and foremost a man of science' (Ross \& Fobes in the edition of Theophrastus, $M e$ taphysica, p. xxv). '[T]he aporetic and anti-dogmatic tendencies in Theophrastus are surely impressive’ (Lloyd 1987: 154). 
those by Aristotle and some of Theophrastus. ${ }^{97}$ The school continued to function centuries after its founder's death, and at least the first few scholarchs continued along very similar lines: in particular, Theophrastus and Strato of Lampsacus (scholarch 288-ca. 269), ${ }^{98}$ besides some other scientifically minded members

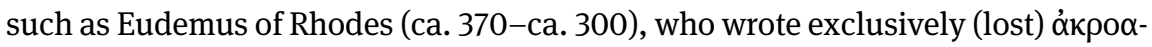

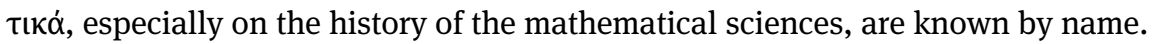
Later on, the difference between public works and those for advanced specialists seems to have become less pronounced and the school seems to have taken a more philological turn. ${ }^{99}$

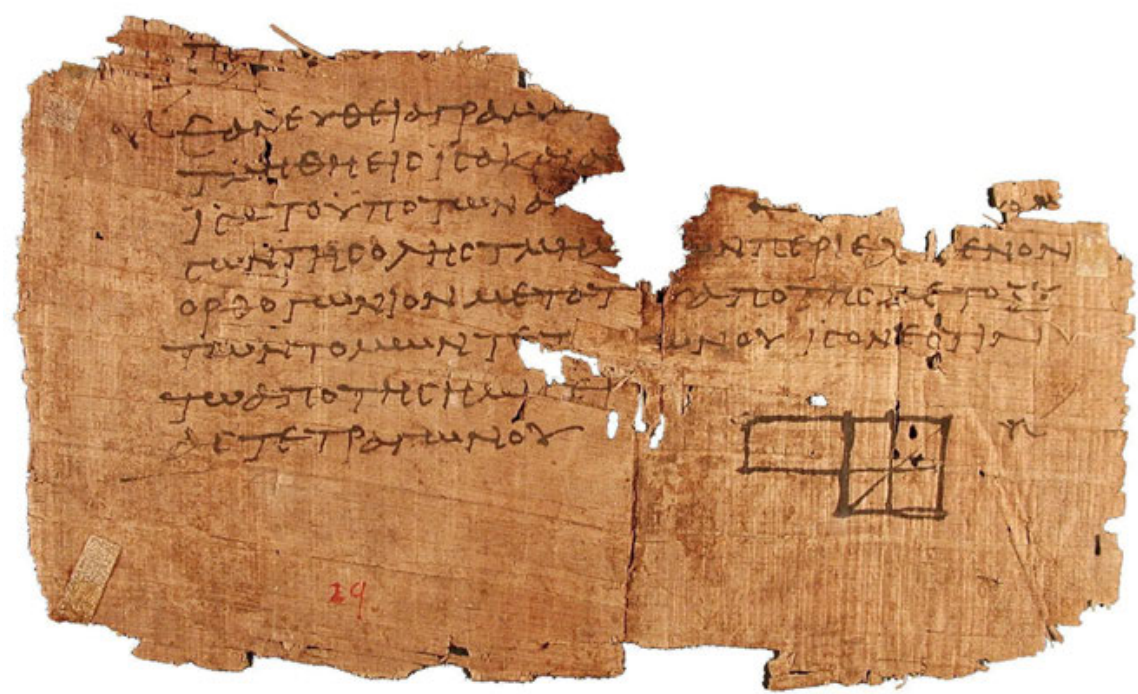

Fig. 10: The oldest known fragment of Euclid's Elementa II, prop. 6, including an unlabelled diagram (Papyrus Oxyrhynchus 29).

Source: https://commons.wikimedia.org/wiki/File:P._Oxy._I_29.jpg (image by user Jitse Niesen, public domain).

97 The fragments of the others are collected by Wehrli (1944-1978).

98 He corrected some Aristotelian mistakes. For instance, he found out that the central organ of thought is the brain, not the heart.

99 Under Lyco of Troas (ca. 269-225), Aristo of Ceos (225-ca. 190), Critolaus (ca. 190-155), Diodorus of Tyre (ca. 140), and Erymneus (ca. 110). With Andronicus of Rhodes (fl. ca. 60 BC) and his apparent recovery of Aristotle's esoteric works, a new era began, one marked mostly by the writing of scientific commentaries on the master's works. 
In Hellenistic times, some schools, especially that at the Museion in Alexandria (in touch with Aristotle's) ${ }^{100}$ and the one in Pergamon, became government sponsored, which, of course, sped up their advances significantly (recall the 'community effort' feature above). Both places also accumulated libraries of hitherto unseen size and quality. An important feature of Hellenistic and Roman times are the philosophical schools. Among them, Aristotle's remained the leading one for science in Antiquity. The other ones, especially the Platonists, Stoics, and Epicureans, focused less on scientific study and much more on ethics, and they tended to be more dogmatic. ${ }^{101}$ Some very important Greek scientific works that were to set standards for the millennia to come were written in these Hellenistic and then, to a lesser degree, Roman times. ${ }^{102}$ Unfortunately, most of Hellenistic science is lost, and we are even hardly informed about centres and schools. Prime examples of texts that became of great importance for the development of science in early modern times are Euclid's Elementa (see fig. 10; linguistically examined in chap. 22 below) for geometry, and from Roman times the works of Hero of Alexandria $^{103}$ for the development of mechanics and physics, as well as those of Ptolemy (ca. 100-ca. 170) for astronomy, and those of Galen (ca. 129-ca. 210) for medicine. Works of other, presumably important, scientific authors such as later Peripatetics, Alexandrian biologists, or the Stoic Posidonius (ca. 135-ca. 51 BC) are lost. Some of the extant authors tell us what they understood غ̇лıбฑ่ $\mu \eta$ to be; for instance, the great astronomer Claudius Ptolemaeus (De iudicandi facultate et animi principatu, ed. Lammert, vol. 3.2, p. 6) writes:

100 On the famous library, see still Parsons (1952); the more recent summaries by Canfora and ElAbbadi cannot be recommended.

101 'Ganz anders das Werk des Aristoteles, welches erstens der Ethik keine beherrschende Stellung einräumte und dann im Gegensatz zu Stoa und Garten mit seiner wissenschaftlich-aporetischen Behandlung aller Probleme auf keine abschließende Dogmatik angelegt war' ('In contrast to the work of Aristotle, which, firstly, did not give a dominant position to ethics and then, in contrast to Stoa and Epicureans, was not pursuing a closed dogma with its scientific-aporetical treatment of all problems'; Wehrli 1944-1978: 10:95).

102 Russo (1997) argues that Hellenism is the real creator of science and that the ensuing Roman and mediaeval times suppressed it, only for it to be regained in Renaissance Latin circles. The importance of Hellenistic science is indeed great, but by finding no science in Aristotle and in the Latin twelfth to fifteenth centuries, it would seem that Russo takes over the biased and seriously dated convictions of some Renaissance humanists, denigrating the 'dark' Middle Ages and university Aristotelianism; see chap. 12 below. Despite this flaw, Russo's book still presents many interesting details in the history of the (especially mathematical) sciences.

103 See Boas (1949). Similar points could be made for Archimedes, Apollonius, or Diophantus, who all become influential in Latin translation in the sixteenth century. 


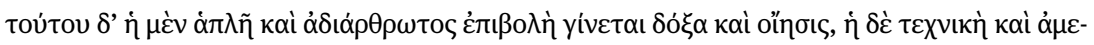

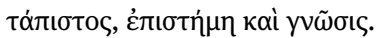

'the simple and unconnected application of it [i.e. thought] becomes opinion and point of view, one that is, according to the rules of art and unmovable by persuasion, science and knowledge.'

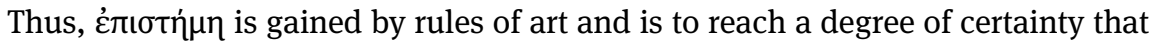
is not easily moved by rhetorical means. Here it is joined by yvw̃oเs, which can depict various types of knowledge (see chap. 3 \$2). Ptolemy also speaks of

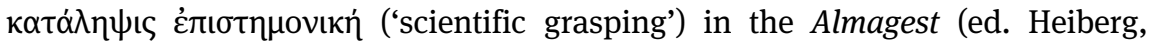

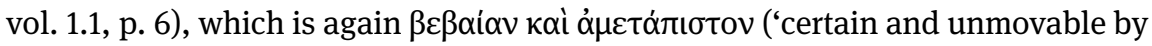
persuasion'). Above, Galen was mentioned for his simile likening theory and observation to the two legs on which science moves forward (chap. 4 §5). The surviving works that have been mentioned changed science fundamentally when they finally became available again to Latin readers: Galen in the twelfth century, Euclid and Archimedes in the thirteenth, and all of them on the brink of the Scientific Revolution (sixteenth century). The rigorous structure of the Elementa, in particular, was to become a rôle model for a truly scientific approach. It was emulated in early modern times, for instance by Tartaglia's Nova scientia (1537), Spinoza's Ethica ordine geometrico demonstrata (1677), or Newton's Principia mathematica (1687). Already in later Antiquity, there were dissenting voices to Aristotle, who did not use mathematical methods in natural science, such as Iamblichus (ca. 245-ca. 325), who advocates the use of mathematics in all sciences (De communi mathematica scientia 32, ed. Festa \& Klein, p. 93):

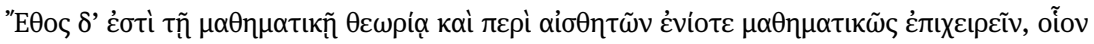

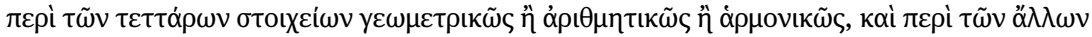

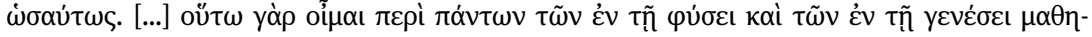

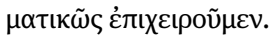

'It is customary for mathematical science to sometimes also tackle physical things, as when considering the four elements in a geometrical or arithmetical or harmonic way, and other fields similarly. [...] Thus, I think we should handle all physical things and all that comes to be in a mathematical way.'
}

What kind of language did these later authors use? The later philosophical schools, especially the Stoics, ${ }^{104}$ continued to use much of the Aristotelian terminology, amplifying it in the fields they were especially interested in. In many scientific fields, the Aristotelian terminology was hardly changed but was used to express new insights. In metaphysics and theology, the neo-Platonists are an ex-

104 For examples of terminology, see Eucken (1879: 31-32). 
ample of this: Plotinus hardly coins new terms (those he does are often compounds in نं $\varepsilon \rho-),{ }^{105}$ but although worldview and metaphysics are very different from Aristotle's (the well-known neo-Platonist hierarchical world of a kind of overflowing divine process in constant flux), he largely used Aristotelian terminology. It may be here that we have, for the first time since Plato (see above), serious scepticism regarding language's capability to describe the deeper layers of 'being' adequately (Enneas VI.8.13, ed. Henry \& Schwyzer, vol. 3, p. 292):

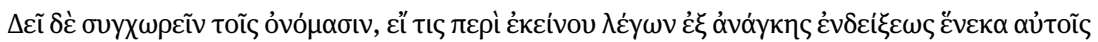

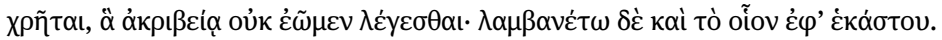

'We have to make a compromise with words whenever somebody necessarily has to use them when speaking about It [the divine One] in order to make apparent what strictly speaking is not expressible. But then a "so to speak" [тò oíov] should always be implied in all cases.'

The further development of Roman and Byzantine science in Greek cannot be followed further here. ${ }^{106}$ Suffice it to say that some fields flourished until the $\ddot{\alpha} \lambda \omega \sigma \mathrm{s}$ (1453) and that they were written in Classical Greek, often using Aristotelian terminology. After two millennia, the Greek scientific and classical language tradi-

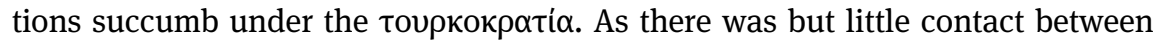
Latin and Greek science in the Middle Ages up to the translation movement in the twelfth century, which relied on pre-Byzantine texts, it is not necessary for the present enterprise to pursue later Greek science and its language further. It may be added that Aristotle is the profane author for whom the greatest number of Byzantine manuscripts survive: more than one thousand. ${ }^{107}$ They were to feed the Latin translation movement.

\$8 So, to summarise, we can recognise a new, scientific Denkstil that can be traced from the sixth century BC and more clearly from the fifth onward, for instance in writers such as Parmenides and Anaxagoras, and somewhat later in a more definite and self-conscious form in some of the Hippocratic medical writers, in historians, and in Democritus; but the crucial factor in the genesis of science was reflection on language and its relation to knowledge. This reflection can be seen in Plato's dialectic, which in turn can be seen as a reply to the sophists' claim

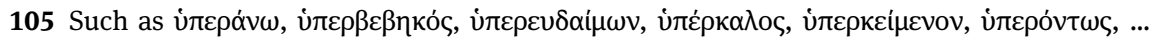
(source: $T L G$ word-list for Plotinus).

106 For the latter, see now Lazaris (2020), which can only partly be recommended; important topics are missing, and (worse) the book is teeming with typographical errors and some chapters are written in appalling English. See still Hunger (1978).

107 In contrast ‘only’ some 260 for Plato (Isépy 2016: 11). 


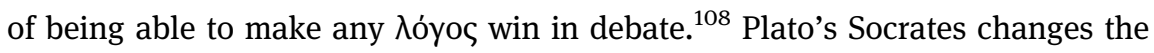
sophists' end - it becomes truth - while keeping their means, as can be well seen, for instance, in Plato's Gorgias. Plato remained sceptical about reaching 'scientific' knowledge of changeable things, and only his pupil Aristotle and his school applied this kind of dialectic inquisitiveness decidedly to all kinds of phenomena, including the changeable world. This may be seen as the actual birth of science, an Aristotelian Denkstil. After Aristotle, many of his scientific and philosophical approaches are further developed. Many of them will be taken up in the Late Middle Ages when they finally reach the Latin medium. Aristotle made some compromises concerning the early ideals of certainty and necessity (see chap. $4 \S 3$ ): he is cautious enough to stress that science describes that which happens all the time or most of the time; besides, there are phenomena that do happen occasionally but neither always nor usually. Whether such phenomena can be and should be described by science does not become clear in Aristotle's works. Modern statistical approaches have been able to group many such occasionally happening phenomena into larger classes and to study them scientifically.

108 A surviving example of such a proclamation is the encomium of Helen by Gorgias, the alleged cause of the Trojan War. 